NBER WORKING PAPER SERIES

\title{
BANKING CRISES WITHOUT PANICS
}

\author{
Matthew Baron \\ Emil Verner \\ Wei Xiong \\ Working Paper 26908 \\ http://www.nber.org/papers/w26908
}

\author{
NATIONAL BUREAU OF ECONOMIC RESEARCH \\ 1050 Massachusetts Avenue \\ Cambridge, MA 02138 \\ March 2020
}

The authors would like to thank Daniel Dieckelmann, Md Azharul Islam, and Jamil Rahman for their extraordinary research assistance. Isha Agarwal, Isaac Green, William Shao, Sylvia Lu, Felipe Silva, Bryan Tam, Yevhenii Usenko, and the librarians at the Harvard Business School Historical Collections also provided valuable assistance. The authors would also like to thank Jason Donaldson, Sam Hanson, Mikael Juselius, Arvind Krishnamurthy, Randy Kroszner, Solomos Solomou, Moritz Schularick, Andrei Shleifer, Eugene White, and seminar participants at the Bank for International Settlements, Boston Fed, Boston University, Cambridge University, Columbia University, Cornell University, Danmarks Nationalbank, EDHEC, Erasmus University Rotterdam, Federal Reserve Board, Georgetown University, Harvard University, Imperial College London, London Business School, MIT, OCC, Oxford University, Richmond Fed, Rutgers University, University of Bonn, University of British Columbia, University of Maryland, University of Rochester, University of Toronto, Yale University, Chicago Booth financial crises conference, fall 2018 NBER Corporate Finance meeting, Becker-Friedman Institute junior finance/macro conference, 2018 AEA meeting, 2019 AFA meeting, Kentucky Finance Conference, Columbia SIPA / BPI financial regulation conference, and the New York Fed/NYU Conference of Financial Intermediation for their comments and feedback. We thank Mika Vaihekoski and Frans Buelens for sharing data. A previous version of this paper was circulated with the title "Salient Crises, Quiet Crises." The views expressed herein are those of the authors and do not necessarily reflect the views of the National Bureau of Economic Research.

NBER working papers are circulated for discussion and comment purposes. They have not been peer-reviewed or been subject to the review by the NBER Board of Directors that accompanies official NBER publications.

(C) 2020 by Matthew Baron, Emil Verner, and Wei Xiong. All rights reserved. Short sections of text, not to exceed two paragraphs, may be quoted without explicit permission provided that full credit, including $\odot$ notice, is given to the source. 
Banking Crises without Panics

Matthew Baron, Emil Verner, and Wei Xiong

NBER Working Paper No. 26908

March 2020

JEL No. G01,G21

\begin{abstract}
$\underline{\text { ABSTRACT }}$
We examine historical banking crises through the lens of bank equity declines, which cover a broad sample of episodes of banking distress both with and without banking panics. To do this, we construct a new dataset on bank equity returns and narrative information on banking panics for 46 countries over the period 1870-2016. We find that even in the absence of panics, large bank equity declines are associated with substantial credit contractions and output gaps. While panics can be an important amplification mechanism, our results indicate that panics are not necessary for banking crises to have severe economic consequences. Furthermore, panics tend to be preceded by large bank equity declines, suggesting that panics are the result, rather than the cause, of earlier bank losses. We also use bank equity returns to uncover a number of forgotten historical banking crises and to create a banking crisis chronology that distinguishes between bank equity losses and panics.
\end{abstract}

Matthew Baron

Johnson Graduate School of Management

Cornell University

401J Sage Hall

Ithaca, NY 14853-6201

baron@ cornell.edu

Emil Verner

MIT Sloan School of Management

100 Main Street, E62-635

Cambridge, MA 02142-1347

everner@mit.edu

\author{
Wei Xiong \\ Princeton University \\ Department of Economics \\ Bendheim Center for Finance \\ Princeton, NJ 08450 \\ and NBER \\ wxiong@princeton.edu
}


The severe economic distress faced by the world economy following the 2008 financial crisis has renewed interest in understanding the causes and consequences of banking crises. Academics and policy makers often emphasize panics among bank creditors as a key driver of banking crises. For example, Friedman and Schwartz (1963) argue that depositor panics played a central role in the severity of the Great Depression, and Bernanke (2018) attributes the unusual severity of the Great Recession primarily to the panics in funding and securitization markets after the collapse of Lehman Brothers. As highlighted by the classic theory of Diamond and Dybvig (1983), using short-term debt to finance long-term illiquid investments exposes even solvent banks to self-fulfilling panics. As a reflection of the influence of the panic-based view of banking crises, some have gone as far as essentially defining banking crises as banking panics (Schwartz 1987, Gorton 2014).

However, there remains a debate about whether panics are so essential to banking crises. Another strand of research on banking crises argues that policy makers should be concerned primarily by bank capital crunches driven by asset losses, rather than panics per se (e.g., Calomiris and Mason 2003, Greenlaw et al. 2008, Admati and Hellwig 2014). This alternative view is motivated by an extensive literature that emphasizes bank equity as a key state variable that determines banks' capacity to intermediate funds from savers to firms and households, e.g., Holmstrom and Tirole (1997) and Gertler and Kiyotaki (2010). As large declines in bank equity tend to impair banks' intermediation capacity, an important question is whether large bank losses even without panics can also translate into severe recessions. If so, large bank equity losses should be viewed as the central feature of banking crises.

We address this debate by asking — are panics necessary for banking crises to have severe economic consequences? Our conceptual definition of a banking crisis is an episode in which the banking sector's ability to intermediate funds is severely impaired. By panics, we mean episodes of severe and sudden withdrawals of funding by bank creditors from a significant part of the banking system. If the answer to this question is no, then a bank capital crunch caused by large loan losses or other impairment of the banking sector can lead to a sharp contraction in credit supply that depresses macroeconomic output, even without a panic.

We use bank equity returns to systemically examine this question, as large bank equity declines capture a sample of episodes in which banks suffer large losses from the viewpoint of 
equity investors, and thus likely capture times of bank distress. Since equity holders are the first to suffer losses from the occurrence of a banking crisis that damages banks' intermediation capacity, we assume that conceptually a large bank equity decline is necessary for a banking crisis. Large bank equity declines offer several advantages as measures of aggregate banking sector distress relative to existing approaches to identifying historical banking crises (e.g., Reinhart and Rogoff 2009, Laeven and Valencia 2013). First, large declines in bank equity cover a broad sample of episodes of banking distress both with and without panics, as episodes without panics may be otherwise hard to detect due to the "quiet" nature of some such episodes of bank distress. Second, in contrast to the information insensitivity of credit-market instruments prior to panics, bank equity returns tend to be gradual and cumulative and thus may capture early signs of banking crises for real-time policy making. Third, the broad availability of bank equity returns across many countries going far back in time makes bank equity returns particularly appealing for studies of historical crises.

We construct a new historical dataset of bank equity index returns for 46 advanced and emerging economies going back to 1870, built in large part from hand-collected individual bank stock price and dividend data from historical newspapers. We control for broader stock market conditions by also constructing new indexes for nonfinancial stocks over the same sample. Our dataset thus provides nearly 2,500 country-years of information on bank equities, nonfinancial equities, and macroeconomic variables. We also collect new information on the occurrence of events such as banking panics and widespread bank failures, backed by several hundred pages of narrative documentation.

As many other factors beyond banking crises may also cause large fluctuations in bank equity returns, one cannot take for granted the empirical performance of bank equity declines in identifying crises and predicting subsequent economic outcomes. We first confirm that bank equity declines contain useful information about banking sector distress and the economy by testing at the country level whether bank equity index returns have predictive content for future macroeconomic dynamics, beyond the information contained in nonfinancial equities. We find that bank equity declines predict large and persistent declines in future real GDP and bank credit to the private sector. For example, a decline in bank equity of at least 30\% predicts 3.4\% lower real GDP and 5.7 percentage points lower bank credit-to-GDP after three years. The relation between bank equity returns and future output and credit growth is highly nonlinear: declines in bank equity 
predict future output and credit contraction, whereas increases in bank equity do not predict stronger economic performance. In contrast, while nonfinancial equity declines also separately predict lower GDP, they have no relation to subsequent bank credit-to-GDP.

Large bank equity declines thus likely pick up episodes when output contracts in part due to troubles in the banking sector. As further confirmation, we find that bank equity declines tend to capture other characteristics associated with banking crises, such as widespread bank failures, high rates of nonperforming loans, and government intervention into the banking sector. By using bank equity declines as a convenient measure of banking distress, our analysis provides broad evidence of the macroeconomic consequences of banking distress across time and countries, complementing previous studies that use cross-sectional variation in specific episodes to offer sharp identification of the macroeconomic consequences of banking distress (Peek and Rosengren 2000, Khwaja and Mian 2008, Amiti and Weinstein 2011, Puri, Rocholl, and Steffen 2011, Chodorow-Reich 2014, and Huber 2018).

To facilitate our analysis of panic and non-panic episodes, we define a "bank equity crash" as a bank equity decline of over $30 \%$ in a year. We then separate these bank equity crashes into panic versus non-panic episodes based on a systematic reading of the narrative evidence for each of these episodes. We define panics as episodes of severe and sudden withdrawals of funding by bank creditors from a significant part of the banking system, which could include withdrawals of funding from either insolvent banks ("fundamental runs") or illiquid but fundamentally solvent banks ("non-fundamental runs"). Our analysis finds that while panic bank equity crashes tend to be followed by greater credit contractions and lower output growth, non-panic bank equity crashes also predict substantial credit contractions and persistent output gaps. For example, even in the absence of any creditor panic, a decline in bank equity of at least $30 \%$ predicts that after three years, bank credit-to-GDP declines by $3.4 \%$ and real GDP declines by $2.9 \%$. This finding suggests that in a large historical sample, panics are not necessary for severe economic consequences, as non-panic episodes can also lead to substantial credit contractions and output drops.

While some of the non-panic bank equity crashes might be solely driven by equity market noise, we show that many are, in fact, well-documented episodes in which the financial system suffered major losses and was undercapitalized, yet strong regulatory forbearance, implicit government guarantees, or outright government intervention prevented panics from emerging 
among bank creditors. To stress their relevance, we highlight several prominent episodes of severe non-panic banking distress, including Canada during the Great Depression, Spain in 1977-1982, the U.S. in 1990-1992, Japan in 1990-1996 and 2001-2003, and several Eurozone countries today - examples which are all associated with prolonged recessions and credit crunches. Our analysis thus motivates policy makers to broaden their policy interventions to cover not just panics on the banking system but also bank capital crunches even in the absence of panics.

One other important advantage of bank equity returns is that they allow for precise analysis of the turning points of historical banking crises and the dynamics of how crises evolve, as understood in real-time by equity investors. We thus zoom in on a sample of crises to examine the timing of large bank equity declines relative to panics. Using monthly data covering over one hundred crises, we find that large bank equity declines tend to precede panics and credit spread spikes. On average, panics, as identified by narrative accounts, occur 7 months after the bank equity index has already declined by $30 \%$. Moreover, prior to the month of the panic, bank equity has declined by an average of $36 \%$ from its previous peak. These results suggest that substantial bank losses are already present at the early stages of these crisis episodes, rather than these losses being due to the subsequent panics. Furthermore, while credit spreads are relatively insensitive to these early losses, bank equity returns are more sensitive, which, while not surprising from a conceptual perspective, nevertheless highlights bank equity declines as a useful crisis indicator for policy making in real-time.

Taken together, our findings paint a more complete picture of the roles played by bank equity declines and panics during banking crises: large bank equity declines tend to be followed by severe economic consequences even without panics; large bank equity declines precede the occurrence of panics; and panics with large bank equity declines tend to have the most severe credit contractions and output gaps. These findings highlight panics as an amplification mechanism, albeit not a necessary condition for severe banking crises. Furthermore, these findings reinforce the importance of timely recapitalization of bank capital during early phases of banking distress, rather than having policy makers simply backstop liquidity, in order to prevent subsequent panics from erupting and to minimize the adverse macroeconomic consequences.

Finally, as a byproduct of our analysis, we provide a new chronology of banking crises that highlights both crises with banking panics and crises with bank equity losses but without panics. 
Prior chronologies of historical banking crises, e.g., Bordo et al. (2001), Caprio and Klingebiel (2003), Demirgüç-Kunt and Detragiache (2005), Reinhart and Rogoff (2009), Schularick and Taylor (2012), and Laeven and Valencia (2013), tend to be subjective in how they designate banking crisis episodes (Romer and Romer, 2017). As a result, these various banking crisis chronologies disagree with one another. We use information from bank equity returns, along with newly collected information on panics and widespread bank failures, to create a more systematic banking crisis chronology. As there is no single correct definition of a banking crisis, our goal is to provide one possible construction of clear-cut crisis episodes based on three systematic criteria: bank equity losses, bank failures, and panics. Importantly, our approach also removes spurious episodes from the previous narrative-based banking crisis chronologies and helps to reconcile disagreements between them. With the help of large bank equity declines as a screening tool, we also uncover a number of "forgotten" historical banking crises that are confirmed by new narrative evidence.

Our paper is organized as follows. Section I discusses conceptual issues. Section II describes our new historical dataset. Section III presents the results on the informativeness of bank equity returns for macroeconomic outcomes. Section IV explores the macroeconomic implications of panics and non-panic bank distress episodes. Section V compares the timing of bank equity declines, panics, and other financial market indicators around banking crises, and Section VI presents our new banking crisis chronology.

\section{Conceptual issues}

This section outlines theories of banking crises and discusses how these theories connect to our empirical bank equity decline measure.

\section{A. Theories of crises}

The classic model of Diamond and Dybvig (1983) has greatly influenced views of policy makers and academics about banking crises. In their model, panics in the form of self-fulfilling multiple equilibria can lead depositors to run on a fundamentally solvent but illiquid bank. This situation arises because banks are funded by demand deposits, a type of short-term debt, which 
exposes banks to nonfundamental panic runs. When other households choose to withdraw their deposits, each depositor finds it optimal to withdraw as well, even if the bank's illiquid assets are able to pay off its liabilities in the long run. When panic runs occur, the bank is forced to liquidate its assets at a discount, leading the bank to fail.

While modern financial systems include non-bank financial institutions and non-deposit funding, short-term debt remains the most important form of financing, thus exposing the banking system to panic runs. Despite the instability it creates, short-term debt is widely used due to several important economic considerations. Calomiris and Kahn (1991) argue that short-term debt financing can serve as a mechanism for lenders to discipline borrowers in the presence of moral hazard. Gorton and Pennacchi (1990) emphasize that when a borrower is far from insolvency, its short-term debt is safe and thus insensitive to private information about its fundamentals, which alleviates adverse-selection problems in financial markets and makes short-term debt liquid in secondary markets. Dang, Gorton and Holmstrom (2019) further argue that the rapid growth of securitization of mortgage loans in the shadow banking sector during the 1990s and 2000s was largely driven by the market demand for information-insensitive securities.

Short-term debt financing also exposes banks and non-bank financial institutions to fundamental-driven panics. In the presence of asymmetric information about the health of a bank, Chari and Jagannathan (1988), Allen and Gale (1998), and Calomiris and Kahn (1991) show that panics occur not only after negative fundamental shocks but also when depositors suffer liquidity shocks, because depositors cannot tell apart these situations. Goldstein and Pauzner (2005) and He and Xiong (2012) develop both static and dynamic models to show that negative fundamental shocks may exacerbate the coordination problem among short-term debt holders, leading to panic runs on a fundamentally solvent bank. In these models, panic runs serve to amplify initial negative fundamental shocks.

These panic-based mechanisms, either through self-fulfilling runs or fundamental-driven runs, tend to occur as discontinuous disruptions in credit markets. Bernanke (2018) provides a summary of credit market disruptions during the 2007-2008 U.S. financial crisis, occurring in asset classes such as asset-backed commercial paper (Kacperczyk and Schnabl 2010; Covitz, Liang, and Suarez 2013; Schroth, Suarez and Taylor 2014), structured investment vehicles and other conduits (Gorton 2008), and money market mutual funds (McCabe 2010). Bernanke (2018) highlights that, 
as these short-term credit-market instruments are by design information-insensitive during normal periods, it is particularly difficult for policy makers to predict the occurrence of panic runs on these instruments and the economic consequences of such runs.

Instead of focusing on disruptions in bank funding markets, this paper explores bank equity declines as an alternative lens to study banking crises. Our analysis is broadly motivated by the literature that emphasizes bank equity as the key determinant of banks' intermediation capacity, e.g., Holmstrom and Tirole (1997), Gertler and Kiyotaki (2010), He and Krishnamurthy (2013), Brunnermeier and Sannikov (2014), and Rampini and Viswanathan (2019). For example, in Holmstrom and Tirole (1997), banks are incentivized to monitor borrowers by investing a sufficiently large stake of their own capital into firms. This implies that banks face an equity constraint with their lending limited by their capital. According to these models, adverse shocks that impair bank equity may constrain banks' capacity to finance the economy, depressing output through a bank capital crunch. ${ }^{1}$

What factors increase the likelihood of bank capital crunches and panics? An extensive literature provides evidence that banking crises are not simply due to random realizations of negative shocks, but rather deeply connected to prior credit booms. Specifically, credit booms predict a higher probability of banking crises (Schularick and Taylor 2012, Baron and Xiong 2017) and coincide with low credit spreads and an increase in debt issuance by riskier borrowers (Greenwood and Hanson 2013, Mian, Sufi, and Verner 2017, López-Salido, Stein, and Zakrajšek 2017, Krishnamurthy and Muir 2018). These findings highlight that elevated sentiment or overoptimism likely plays a central role in credit booms. Following a period of positive shocks, lenders may over-extrapolate recent low defaults and neglect downside risk, leading to the underpricing of risk during the credit boom and subsequent bank asset losses (Bordalo, Gennaioli, and Shleifer 2018, Greenwood, Hanson, and Jin 2019). Overall, credit booms increase the fragility of the banking system and the economy, leaving banks vulnerable to future losses that lead to bank capital crunches or even panics.

\footnotetext{
${ }^{1}$ He and Krishnamurthy (2013) also highlight a subtler channel beyond the bank lending channel: shocks to bank health may depress asset prices, which in turn lowers the ability of households and firms to access credit due to household and firm balance sheet constraints.
} 


\section{B. Research questions}

The contrasting emphasis of the two strands of the literature on panics and bank equity losses motivates our research questions:

Are large bank equity declines associated with adverse macroeconomic consequences? An extensive literature examines the macroeconomic consequences of bank distress by analyzing the effects of sharply identified shocks to the banking sector. Peek and Rosengren (2000) and Amiti and Weinstein (2011) use shocks from Japanese banks, which affected economic activity in the U.S. and Japan; Khwaja and Mian (2008) analyzes a bank credit supply shock created by a political event in Pakistan; Chodorow-Reich (2014) exploits the Lehman bankruptcy during the Great Recession as a credit supply shock to study its effect on U.S. employment; while Huber (2018) studies the effects of domestic lending cuts by Commerzbank, a large bank that suffered significant losses in its international trading book. While these studies offer sharp identification, they are limited to the specific countries and time periods in their respective samples, thus leaving open the question regarding whether severe economic consequences of bank distress exist in a broad sample that spans time and space. By addressing this question, we are also able to establish the empirical performance of bank equity declines as a way of measuring banking distress.

Are panics necessary for banking crises to have severe economic consequences? Bank equity prices allow us to address this question, as large equity declines capture a sample of episodes in which banks suffer large losses from the viewpoint of equity investors. Since a large bank equity decline is necessary for a banking crisis, ${ }^{2}$ these episodes include both those that have experienced banking panic and those without, and thus allow us to separately examine macroeconomic consequences of large bank equity declines with and without observations of panics. Banking crises without panics may occur when banks are undercapitalized and their ability to lend is severely impaired, even when panics by bank creditors are prevented, often due to a combination of regulatory forbearance, implicit creditor guarantees, and forceful government interventions.

\footnotetext{
${ }^{2}$ However, as we will show, measurement error can lead to observations of narrative accounts of bank panics that are not associated with large equity declines for at least two reasons. First, because our bank equity index primarily covers large commercial banks, our bank equity index may not reflect runs on private bank, regional banks, or nonbank financial institutions are not captured by our bank equity index. Second, panics without large bank equity crashes declines can also be episodes of short-lived panics, in which long-run bank solvency is not affected and bank equity thus recovers by the end of the year.
} 
These banking crises without panics may reflect episodes with narrative evidence of bank failures. ${ }^{3}$ However, importantly, bank equity declines also allow us to go one step further and identify episodes of banking sector distress with neither panics nor narrative evidence of bank failures, which we refer to as quiet crises. These quiet crises may reflect bank losses that do not translate into headline events such as panics or bank failures, but where losses nevertheless impair banks' ability to lend. Narrative-based approaches often miss such quiet episodes due to the difficulty of detecting banking losses in the absence of salient characteristics such as depositor runs or bank failures, as acknowledged by early studies that use narrative-based approaches, e.g., Caprio and Klingebiel (1996, 2003).

Do bank equity declines precede panics? The joint dynamics of bank equity returns, panics, and credit-market spreads allow us to systematically examine the relative timing of bank equity declines, panics, and credit-market disruptions around banking crises. If panics are driven by selffulfilling shocks unrelated to bank fundamentals, they would not be preceded by bank equity declines. Thus, evidence of bank equity declines preceding subsequent panics helps to link panic runs to prior bank losses, rather than non-fundamental runs causing bank losses.

We further compare the timing of bank equity declines with the timing of credit spread spikes, which reflect disruptions in credit markets. The lower sensitivity of credit-market instruments to bank fundamentals leads us to expect that bank equity declines should detect crises earlier than credit-market measures. As bank equity has the lowest payoff priority among all bank stakeholders, bank equity prices should be sensitive to bank losses regardless of whether a bank is close to or far away from insolvency. As a result, bank equity returns would be expected to provide a continuous and cumulative measure of bank distress, in contrast to prices of credit-market instruments, especially short-term debt instruments, which tend to display discontinuities around panics. Nevertheless, their actual power in a large sample remains to be systematically examined.

\section{Mapping historical banking crises}

In contrast to our approach emphasizing bank equity returns to identify periods of banking distress, the traditional approach in the literature (e.g., Reinhart and Rogoff 2009, Schularick and

\footnotetext{
${ }^{3}$ Examples of bank failures without panics include situations when banks are orderly wound down or restructured through judicial bankruptcy proceedings, merged by the government with a healthy bank, or nationalized.
} 
Taylor 2012, Laeven and Valencia 2013) identifies banking crises based on narrative accounts of salient features such as bank runs, bank failures, and large-scale government interventions. Romer and Romer (2017) point out that because narrative-based approaches are subjective and retrospective, they may contain look-back biases that lead to an overstatement of average banking crisis severity. Other drawbacks of narrative approaches include the treatment of crises as discrete episodes (when a continuum between "normal recessions" and banking crises might be a more accurate representation) and the lack of quantitative measures of bank impairment to distinguish between minor versus major crises. These various narrative approaches also disagree with each other about which episodes should be regarded as banking crises. Table 1 highlights this disagreement in the case of Germany, while Table A1 shows this problem across all countries. ${ }^{4}$ This disagreement is due in part to a lack of a consistent definition of which features constitute a banking crisis. ${ }^{5}$ And, importantly, these traditional narrative-based approaches of identifying historical banking crises may miss episodes without panics or other salient characteristics, due to the difficulty of detecting banking losses in the absence of such salient features.

In contrast to historical narrative accounts, bank equity returns provide an objective, realtime, quantitative, and theoretically motivated measure to map out historical periods of bank distress from the viewpoint of equity investors. Bank equity has strong predictive power for macroeconomic consequences, as we show, both in terms of the magnitude and signal-to-noise ratio. Furthermore, bank equity price and dividend data are readily available over much of the sample, covering 46 countries over the period 1870-2016, in contrast to corporate bond and interbank lending spreads, which are relatively limited historically. ${ }^{6}$ Finally, using bank equity

\footnotetext{
${ }^{4}$ Jalil (2015) discusses this disagreement among narrative chronologies in the case of U.S. pre-1929 banking crises.

${ }^{5}$ Moreover, these approaches (with the exception of Laeven and Valencia 2013) have minimal historical documentation for each banking crisis episode, making it difficult for other researchers to reconcile these differences between approaches or even to assess the basic facts of what happened during each crisis. Reinhart and Rogoff (2009) and Caprio and Klingebiel (2003) write only a few sentences about each crisis, while Bordo et al. (2001)'s database mainly presents macroeconomic variables. Schularick and Taylor (2012) do not provide publicly available documentation to support their chronology; in personal correspondence, the authors say their chronology is constructed by surveying country-specific experts in banking history in 17 countries.

${ }^{6}$ Bond markets in many countries have only been developed in recent decades. In the postwar period, corporate bond markets mainly existed in the U.S. and U.K., while in most non-Anglophone advanced economies, corporate bond markets were very limited or non-existent until deregulation in the 1980s (as corporate credit was channeled mainly through the banking system). For example, there was only a single corporate bond each trading in Denmark and Japan before the 1980s (that of Det Store Nordiske Telegrafselskab and Nippon Telegraph and Telephone, respectively). Even organized interbank markets are a relative recent phenomenon, with data becoming available for most countries starting in the 1990s. As a result, Krishnamurthy and Muir (2018) analyze a more limited sample, since they do not
} 
returns does not rely on observing salient features, allowing us to capture a larger sample of episodes of bank distress, which is key to our purpose of studying episodes without panics.

\section{Data}

We now describe how we gather and construct the historical database used in our analysis. We discuss, in turn, the following types of variables: bank and nonfinancial equity real total returns, bank and nonfinancial credit spreads, and macroeconomic variables. All variables are annual (except those noted as monthly variables) and form an unbalanced country panel across 46 countries over the period 1870-2016. ${ }^{7}$ The Appendix contains further details on data sources and data construction beyond what is presented here, and Tables B2 through B4 provide a comprehensive summary by country of all data sources used to construct the main variables.

Annual bank and nonfinancial stock returns. We construct a new historical dataset on bank equity prices and dividends for 46 advanced and emerging economies going back to 1870 . A practical advantage of bank equity returns to study crises is that bank equity price and dividend data are readily available over much of our sample. This abundance of data is due to the fact that, in the $19^{\text {th }}$ and early $20^{\text {th }}$ centuries, bank stocks were highly prominent, featured in newspapers and traded as much as railroad stocks. ${ }^{8}$

For each country in the sample, we construct annual (as of December 31 of each year) price return and dividend return indexes for both bank and nonfinancial stocks. In this paper, all equity returns (unless otherwise noted) are expressed as real total returns of the country-level index. The

have corporate credit spread data for emerging market countries - or even for many advanced economies (Denmark, Italy, France, the Netherlands, and Switzerland) in the modern period.

${ }^{7}$ We exclude country-year observations during major wars because supply-side contractions and large government financing needs can lead to both macroeconomic contractions and banking sector losses, but these are not the typical banking distress episodes we want to consider. In particular, we drop all countries during the world wars (1914-1918 and 1939-1945), Korea during 1950-53, Spain during 1936-1938, France and Germany in 1870, Mexico during 19101920, South Africa during 1899-1902, Japan during 1894-1895, Colombia during 1899-1902, Russia during 19171922, and Greece during 1946-1949.

${ }^{8}$ In the period 1870-1939, nearly all the major commercial banks in all our countries were publicly-traded joint stock banks, much more so than even today - the main exception being the U.S., where banks were not widely traded until the mid-1920s. (In fact, even most central banks were publicly traded in that period, though we do not include them in our indexes). The private banks of this period were generally either merchant banks or mortgage banks, not commercial banks. We are thus able to gather the stock prices and dividends of nearly all large commercial banks in each country from historical newspapers during this period. 
price and dividend indexes in a given country may not necessarily correspond to the exact same underlying banks due to data availability, but they are either market-capitalization-weighted or price-weighted indexes of the broad domestic banking and nonfinancial sectors within each country. ${ }^{9}$ Each of these series is pieced together from a variety of sources (documentation and source tables can be found in the Appendix). ${ }^{10}$ We start by collecting premade bank equity indexes from Global Financial Data (mainly price indexes), Datastream (price and dividend indexes), and Baron and Xiong (2017, newly constructed bank dividend indexes).

In addition to using premade indexes, we construct bank equity price and dividend indexes from individual bank and nonfinancial companies' stock prices and dividends. Our main source of new data on individual stocks comes from historical newspapers in each country. From these newspapers, we hand collect prices and dividends on an annual basis for the closing price closest to December $31 .{ }^{11}$

Data on individual stock prices and dividends of banks and nonfinancial firms also come from several databases from Yale's International Center for Finance (gathered and made publicly available by William Goetzmann and Geert Rouwenhorst) including Investor's Monthly Manual data (1869-1934), New York Stock Exchange data (1800-1871), and St. Petersburg Stock Exchange data (1865-1917). Other data on individual stock and index returns are from a variety of additional sources including individual country studies and statistical yearbooks. Additional dividend data for individual bank and nonfinancial stocks is hand-collected from Moody's Banking

\footnotetext{
${ }^{9}$ In price-weighted indexes, each stock is normalized to the same par value in the initial year. Its weight in subsequent years is then determined by past returns.

${ }^{10}$ The nonfinancial equity index is constructed to represent a diverse set of important and large companies, mainly covering the following industries: iron and steel, goods manufacturing, electrical equipment, textiles, chemicals, paper and pulp products, food suppliers and breweries, and retail. We exclude transportation stocks (railroads and shipping), commodity-related stocks (including mining), utilities, real estate companies, and foreign and colonial enterprises, due to their high exposure to international factors or to real estate.

${ }^{11}$ Figure A1 in the Appendix provides examples of historical newspapers used to construct our bank equity return data. To give a sense of the sheer number and diversity of historical sources we uncovered, we list the main ones here (the full list is available in Table B2): Journal de Bruxelles for Belgium (1868-1935); Dagens Nyheder for Denmark (1868-1909); Le Temps for France (1873-1939); Berliner Borsen-Zeitung and Berliner Morgenpost for Germany (1871-1933); La Stampa for Italy (1865-1934); Japan Times for Japan (1897-1915); De Telegraaf and De Standaard for the Netherlands (1875-1933); Diario de Lisboa for Portugal (1921-1990); the Straits Times for Singapore (19651980); ABC for Spain (1909-1965); and Gazette de Lausanne, Journal de Genève, Le Temps, and Neue Zürcher Zeitung for Switzerland (1852-1936). We also collect stock returns data from a variety of additional sources: Argentinian stock returns data (1900-1935) from Nakamura and Zarazaga (2001); Belgian stock returns data from the SCOB database (University of Antwerp, Belgium); Danish stock returns data (1911-1956) from Denmark Statistical Yearbooks; Finnish stock returns data (1911-1974) from Nyberg and Vaihekoski (2010); and Swedish stock returns data (1870-1901) from Waldenstrom (2014).
} 
Manuals (1928-2000) and from individual financial statements of banks accessed at the Harvard Business Library's Historical Collections. We add the bank equity price returns and dividend returns to get bank equity total returns and then adjust by the CPI for each country to get bank equity real total returns. Figure A3 plots the distribution of bank and nonfinancial equity returns around banking crises defined by narrative-based approaches.

The bank equity returns data start around 1870 for advanced economies such as Australia, Austria, Belgium, Canada, France, Germany, Ireland, Italy, New Zealand, Sweden, Switzerland, the U.K. and the U.S. and even for economies that are today considered emerging markets such as Argentina, Brazil, Egypt, Greece, Hong Kong, India, Mexico, Russia, and Ottoman Turkey. To assess the coverage of our bank index, Table B1 reports, for each country and decade, the number of underlying banks used to construct the bank equity return index, or, when premade indexes are available, the source of the premade index. The exact range of included banks varies across countries and historical periods, due to historical data limitations. However, as can be seen both from Table B1 and the associated lists of individual constituent banks (linked in the Appendix), the bank equity index generally contains a broad representation of the largest domestically chartered commercial banks mainly located in the country's financial center and covering a substantial share of the country's bank assets and deposits. For many countries, our newly constructed bank equity index is based on underlying returns for at least five banks (and often much more), almost always the largest. It is important to note that the focus on large commercial banks in the country's financial center may lead the bank equity measure to underrepresent banking crises centered on smaller or provincial banks and fail to capture distress of private banks.

Monthly stock returns and credit spreads for banks and nonfinancials. To analyze the dynamics of how crises unfold, we also focus on a newly-constructed set of clearly identified banking crisis episodes. We refer to the sample of clear-cut crisis episodes as the BVX Crisis List (which we described in detail in Section VI). For these clear-cut crisis episodes, we construct monthly series in a three-year window around each episode for the following four variables: bank equity index returns, nonfinancial equity index returns, bank credit spreads, and nonfinancial corporate credit spreads. Due to limitations on historical data availability, the monthly data is a smaller subset of the larger annual dataset on bank equity returns and only covers around 100 crisis episodes. 
The complete list of sources for monthly equity returns and credit spreads for each country is recorded in Table B3. For monthly bank and nonfinancial equity data for the period 1980-2016, we mainly use country-level indexes from Datastream, which covers nearly all 46 countries. For the period 1870-1979, the monthly equity data is limited to fifteen countries (Argentina, Australia, Belgium, Denmark, France, Germany, Italy, Japan, Netherlands, Norway, Spain, Sweden, Switzerland, U.K., and U.S.) and three-year windows around banking crises, due to the difficulty of hand-collecting monthly data from historical records. In this period, monthly bank and nonfinancial stock prices are transcribed from the historical newspapers listed in the previous section or obtained from other historical sources such as Investor's Monthly Manual and Global Financial Data (see Table B3 for details). Credit spreads mainly come from Global Financial Data or from newly transcribed historical statistics (again, see Table B3). Bank credit spreads are typically from overnight interbank lending rates, while corporate credit interest rates are from corporate bond yields. We subtract a short-term Treasury bill yield (typically three-month maturity) to get the bank credit spread and a long-term Treasury bond yield (typically 10-year maturity) to get the corporate credit spread.

Macroeconomic variables. To construct real GDP growth, we obtain annual data for each country on nominal or real GDP and the CPI from the Maddison database, the Jordà-SchularickTaylor macro-history database, Global Financial Data, and the OECD, IMF, and World Bank datasets. The same CPI used to deflate returns is used to obtain real GDP. Data on bank credit-toGDP comes mainly from the Jordà-Schularick-Taylor database (which goes back to 1870 but for 17 countries only) and from the BIS long credit series for other countries. We supplement these existing datasets on bank credit-to-GDP with newly transcribed data from: (i) IMF print statistical manuals from the 1940s and 1950s, and (ii) "League of Nations: Money and Banking Statistics" volumes from 1925 to 1939. These new data allow us to form aggregate bank credit-to-GDP series going back at least to 1918 for nearly all the countries in our sample and back to 1870 for a subset of those. The complete list of sources for each variable is recorded in Table B4.

Narrative accounts of crises. To compare the information contained in bank equity declines with the information content from narrative-based approaches, we construct a list of "Narrative Crises," defined as the union of all banking crises from six prominent papers: Bordo et al. (2001), Caprio and Klingebiel (2003), Demirgüç-Kunt and Detragiache (2005), Laeven and Valencia (2013), Reinhart and Rogoff (2009, and online update 2014), and Schularick and Taylor (2012, 
online update 2017). Table A1 reports the Narrative Crisis list. We define the "Narrative Crisis year" as the earliest reported starting year of each banking crisis across the six papers.

The BVX crisis list. We systematically combine information on large bank equity declines with a new database of episodes of panics and widespread bank failures to create a chronology of historical banking crises, which we refer to as the BVX Crisis List. Details on constructing the new chronology are discussed further in Section VI. This new database on episodes of panics and widespread bank failures is reported in Table A2, and links to our extensive historical documentation on episodes of panics and widespread bank failures can be found in Appendix Section I.B.

\section{Bank equity declines and future macroeconomic dynamics}

In this section, we examine the predictive power of large bank equity declines for subsequent economic outcomes such as real GDP and bank credit-to-GDP, without being concerned by whether these declines are accompanied by banking panics. By showing that large bank equity declines tend to precede severe economic outcomes, this analysis serves to establish that bank equity declines are not simply equity market noise and instead carry important information. It thus highlights the potential relevance of bank capital crunches in a long and broad macroeconomic sample and justifies our use of large equity declines to analyze banking crises.

\section{A. Real GDP and credit dynamics around bank equity crashes}

As an initial exploration of the data, we start by examining how real GDP and bank creditto-GDP evolve around bank equity crashes compared to times without crashes. Our definition of a "bank equity crash" is an annual bank equity decline of more than $30 \%$. In our full sample, there are 263 country-years with a 30\% bank equity crash and 209 when we restrict the sample to observations with non-missing GDP growth, credit-to-GDP, and nonfinancial equity returns.

Figure 1 presents an event study around these bank equity crashes. We compute the average cumulative change in log real GDP and credit-to-GDP around bank equity crashes relative to five years before the crash. Year $t=0$ is defined as the year of the bank equity crash. For reference, we also plot the average dynamics around normal times, defined as years without a crash. Panel A 
in Figure 1 shows that, in the years leading up to a bank equity crash, GDP growth is similar to growth in normal times. However, in the year after the crash growth slows sharply, opening an output gap of $4 \%$, which persists even five years after the crash.

In contrast to real GDP, credit-to-GDP expands rapidly in the run-up to bank equity crashes. On average, credit-to-GDP expands by 8.3 percentage points in the five years preceding a crash, relative to 5.1 percentage points during other periods. This pattern is consistent with the evidence in Baron and Xiong (2017) that credit expansions predict bank equity crashes and shows that this result holds for a broader and longer sample. After the crash in bank equity, credit-to-GDP stops expanding and starts declining. This event study thus provides preliminary evidence that bank equity crashes are preceded by credit booms and followed by contractions in output and bank credit-to-GDP.

\section{B. Bank equity declines and future GDP growth}

We next examine the predictability of large bank equity declines for subsequent GDP growth more formally. To flexibly estimate such predictability and explore potential nonlinearities, we estimate the following Jordà (2005) local projection specification for horizons $h=1, \ldots, 6$ :

$$
\Delta_{\mathrm{h}} y_{i, t+h}=\alpha_{i}^{h}+\sum_{j} \beta_{j}^{h} 1\left[r_{i, t}^{B} \in B_{j}\right]+\sum_{j} \delta_{j}^{h} 1\left[r_{i, t}^{N} \in B_{j}\right]+\Gamma^{\mathrm{h}} X_{i, t}+\varepsilon_{i, t}^{h} \text {, }
$$

where $\Delta_{\mathrm{h}} y_{i, t+h}$ is real GDP growth from year $t$ to $t+h, \alpha_{i}^{h}$ is a country fixed effect, and $1\left[r_{i, t}^{B} \in\right.$ $\left.B_{j}\right]$ is an indicator variable for whether the bank equity return in year $t$ is within a range defined by bin $B_{j}$. The indicator $1\left[r_{i, t}^{N} \in B_{j}\right]$ is similarly defined but for nonfinancial equity returns. To examine the predictability across the full distribution of returns, we include eight evenly-spaced bins, $B_{j}$, for both bank and nonfinancial returns: less than $-45 \%,-45 \%$ to $-30 \%,-30 \%$ to $-15 \%$, $15 \%$ to $0 \%, 0 \%$ to $15 \%, 15 \%$ to $30 \%, 30 \%$ to $45 \%$, and greater than $45 \%$. The omitted bin is the $0 \%$ to $15 \%$ range, which we think of as returns during "normal" times. Relative to the traditional VAR framework, the advantage of the local projection method is that it is robust to misspecification and allows for the estimation of nonlinearities and state-dependent responses, as argued by Jordà (2005).

Equation 1 controls for contemporaneous $(t-1$ to $t)$ and lagged real GDP growth and the bank credit-to-GDP change, as well as lags of the bank and nonfinancial equity return bins, 
captured by $X_{i, t}$. We include three annual lags for all variables, but the results are not sensitive to the lag length. Our baseline specification does not include year fixed effects to exploit time series variation within countries, but year fixed effects are included in robustness tests. We compute Driscoll and Kraay (1998) standard errors with a lag length of six to allow for serial correlation in $\varepsilon_{i, t}^{h}$ that mechanically arises from overlapping observations at horizons $h>1$ and residual correlation across countries induced by common shocks. When reporting statistical significance based on $p$-values, we employ Kiefer and Vogelsang's (2005) fixed-b asymptotic distribution to correct for the tendency of heteroskedacity and autocorrelation consistent (HAC) variance estimators to over-reject in finite samples.

The key parameters of interest are the sequence of local projection impulse responses $\left\{\beta_{j}^{h}\right\}$ for each bin $j$, which capture the predictive power of bank equity returns after controlling for nonfinancial returns and current and lagged economic conditions. Note that after controlling for contemporaneous nonfinancial returns, bank equity declines reflect shocks from two sources. First, they may reflect banks' loan losses in the current period. Second, as equity prices are forwardlooking, they may also reflect the stock market's anticipation of banks' losses in future periods. Thus, the impulse responses capture not only the impact of banks' current losses on the broad economy, as a result of banks' reduced capacity to lend to firms and households, but also the anticipated interactions between future economic downturns and future bank losses. For the purpose of our analysis, it is not particularly important to isolate these two effects. ${ }^{12}$ Bank equity is probably also informative for reasons other than a banking channel: for example, bank equity declines may also reflect the macroeconomic consequences of household balance-sheet distress, as households are on the other side of bank lending.

The left plot in Figure 2 Panel A depicts the cumulative response of real GDP to bank equity return innovations. Relative to "normal times" ( $0 \%$ to $15 \%$ returns), declines in bank equity of greater than $45 \%$ predict $3.6 \%$ lower output after three years. Note that Equation 1

\footnotetext{
${ }^{12}$ A more nuanced question is why bank equity declines contain information content about the broad economy not captured by contemporaneous nonfinancial equity returns, which are supposed to reflect all information available about nonfinancial sectors. We can think of at least two possible mechanisms. First, banks tend to provide credit to households and small firms, which are not be fully represented by equity returns of nonfinancial firms. Second, stock market participants may not immediately recognize the full consequences of banking sector losses for the broad economy. The finance literature has offered extensive evidence that stock prices may often underreact to public information. For example, Baron and Xiong (2017) show that stock prices do not fully reflect risks brought by banks' credit expansions.
} 
simultaneously estimates the responses to changes of both bank and nonfinancial equities, so that the response plotted on the left side of Panel $\mathrm{A}$ is the additional response to bank equity returns over-and-above the response to nonfinancial equity returns (which is plotted on the right side of the panel). This negative effect is highly persistent, translating into a permanent loss in output after 6 years of about $3 \%$. More moderate but still substantial shocks of $-30 \%$ to $-45 \%$ are followed by $2.5 \%$ lower output after 3 years, with some subsequent recovery. In contrast, smaller negative shocks of $-15 \%$ to $0 \%$ and positive shocks lead to weaker effects on future GDP.

The strong impact of large negative bank equity returns but weaker impact of positive returns provides evidence that shocks to bank equity have nonlinear predictive content for the real economy. This nonlinear relationship between bank equity distress and output growth is consistent with models of constrained intermediaries such as He and Krishnamurthy (2013), and highlights the advantage of bank equity returns as a continuous measure of banking sector distress. Interestingly, Romer and Romer (2017) find no evidence of nonlinearity between a continuous narrative measure of financial distress and subsequent output, while Adrian et al. (2019) find evidence of asymmetry in the response of GDP growth to financial conditions in U.S. data.

The right plot in Figure 2 Panel A shows the GDP response to nonfinancial equity shocks. Unsurprisingly, larger declines in nonfinancial equity predict lower subsequent output. In contrast with bank equity returns, there is less evidence of nonlinearity in the predictive power of nonfinancial equity returns. The ability of nonfinancial equity returns to predict future GDP growth is consistent with Stock and Watson (2003) and justifies nonfinancial equity returns as a suitable control for shocks to the broad economy.

Table 2 presents the regression version of Figure 2 at the 1- and 3-year ahead horizons. For expositional purposes, we replace the eight return bins with an indicator variable for whether there is a bank equity crash, $1\left[r_{i, t}^{B} \leq-30 \%\right]$, which is defined by an annual return below $-30 \%:{ }^{13}$

$$
\Delta_{\mathrm{h}} y_{i, t+h}=\alpha_{i}^{h}+\gamma_{t}^{h}+\beta^{h} 1\left[r_{i, t}^{B} \leq-30 \%\right]+\delta^{h} 1\left[r_{i, t}^{N} \leq-30 \%\right]+\Gamma^{\mathrm{h}} X_{i, t}+\varepsilon_{i, t}^{h}
$$

We report results with and without including year fixed effects $\gamma_{t}^{h}$. In Table 2 Panel A, a bank equity crash of at least $30 \%$ is associated with a decline in real GDP of about $2.6 \%$ after one year

\footnotetext{
${ }^{13}$ Appendix Table A3 presents the table version of Figure 2 with all eight return bins for the three-year forecast horizon.
} 
(column 2) and 3.4\% after three years (column 5), with the estimated coefficients being statistically significant. A crash of $30 \%$ in nonfinancial equity also predicts significant and persistently lower real output, and the magnitude is similar to the impact of a bank equity crash.

C. Bank equity declines and future bank credit growth

Why do bank equity declines predict lower future GDP growth, even controlling for nonfinancial equity returns? In this subsection, we show that the bank lending channel may play a key role.

Figure 2 Panel B presents estimates of Equation 1 with the change in bank credit-to-GDP as the dependent variable. The left plot shows that, after 6 years, a bank equity decline of over $45 \%$ predicts a 12 -percentage point decline in credit-to-GDP, controlling for nonfinancial equity. Declines of between $30 \%$ and $45 \%$ also predict sizeable credit contractions, amounting to a creditto-GDP decline of 8 percentage points after 6 years. Table 2 Panel B presents the regression version of Figure 2 Panel B using the 30\% bank equity crash indicator. It shows that the decline in creditto-GDP following a bank equity crash is statistically significant and robust to including controls.

Figure 2 Panel B also shows that the response of credit-to-GDP to bank equity return shocks is highly nonlinear. Large declines in bank equity are followed by sharp credit contraction, but smaller declines $(0 \%$ to $-15 \%)$ and increases in bank equity are followed by muted changes in bank credit. This nonlinearity in credit growth is again consistent with models in which banks are financially constrained. Larger shocks to bank net wealth are more likely to force banks against their capital constraint and therefore to contract the asset side of their balance sheet.

The right plot in Figure 2 Panel B presents the credit-to-GDP response to nonfinancial equity shocks. There is a striking contrast between bank equity and nonfinancial equity shocks. Nonfinancial equity shocks have essentially no predictive content for future credit-to-GDP. Even large declines or increases in nonfinancial equity returns have no impact on the subsequent creditto-GDP ratio. This sharp contrast provides one potential explanation for why bank equity shocks matter for future growth, even after we control for nonfinancials. Bank equity declines likely capture shocks to bank net wealth, which translate into a credit-supply contraction that may depress household consumption, corporate investment, and production. 
D. Robustness, subsamples, and further evidence on the informativeness of bank equity

The strong relation between bank equity crashes and subsequent output and credit contraction is highly robust to alternative specifications. Appendix Figure A4 shows that the results in Figure 2 are quantitatively similar when including year fixed effects to control for global shocks. Figure A5 explores an alternative timing in which bank equity returns impact real GDP and credit-to-GDP in the same year. Since bank equity returns are correlated with contemporaneous GDP growth, this specification implies that bank equity crashes are associated with even larger output and credit contractions. Panel A in Figure A6 shows that a simpler specification with just a single indicator variable for $30 \%$ bank equity crashes (as in Table 2) predicts persistent output gaps and credit-to-GDP contraction. Panel B presents another alternative specification showing the responses to continuous innovations in bank and nonfinancial equity returns, rather than using indicator variables. This specification assumes a linear relation between innovations to returns and subsequent outcomes. Panel B shows that shocks to both bank equity and nonfinancial equity predict subsequent output growth. The right plot shows that only bank equity returns predict future credit-to-GDP. Table A4 shows that the nonlinear relation between bank equity returns and subsequent output and credit also emerges using a quadratic specification or separating positive and negative returns.

Figure A7 and Table A5 estimate the responses to 30\% bank and nonfinancial equity crashes for various subsamples. Figure A7 Panel A excludes the Great Depression and Great Recession years. Specifically, we drop years 1927-1937 and 2005-2015 for all countries and find similar estimates to the full sample. Panel B focuses on the prewar sample and finds more modest effects of bank equity crashes on both real GDP and credit-to-GDP. In contrast, Panel C shows that effects are stronger in the postwar period. The postwar results hold in the Bretton Woods Era (1946-1970, Panel D) and in recent decades (1971-2016, Panel E). The fact that bank equity crashes predict output declines and credit contraction during the Bretton Woods Era, a period without major banking crises according to narrative chronologies, suggests a role of bank equity distress outside of traditionally defined banking crises and even during normal recessions. We explore this point further in Section IV. Figure A8 presents estimates for the United States only 
and finds qualitatively similar results, even when excluding the Great Depression and Great Recession. $^{14}$

In addition to having strong predictive power, large bank equity declines line up closely with existing narrative classifications of banking crises in terms of signal-to-noise properties. To explore the signal-to-noise properties of bank equity returns, Figure A2 shows that bank equity returns provide the best real-time signal of banking crises on the list of Narrative Crises identified by existing classifications, relative to a host of other variables including nonfinancial equity returns, credit spreads, and macroeconomic conditions. See the full discussion in Appendix Section II.A. Specifically, bank equity declines best coincide with banking crises identified from existing classifications in terms of the signal-to-noise ratio (i.e. a higher "true positive" rate for a given "false positive" rate, relative to other indicators). 57\% of crises identified by narrative-based approaches involve a bank equity crash of at least $30 \%$ in the year of the crisis or in adjacent years. This further validates large bank equity declines as a reasonable measure of banking distress.

As a final test to illustrate the informative content of bank equity returns, we focus on the predictive content of bank equity declines conditional on Narrative Crisis episodes. Table A6 shows that the magnitude of the peak-to-trough bank equity decline of each Narrative Crisis episode is associated with the magnitude of the decline in real GDP and with crisis characteristics such as the severity of deposit withdrawals, nonperforming loans, bank failures, and the likelihood of various forms of government interventions to support the banking sector. These findings are not driven by general declines in equity markets, as they also hold, albeit not as strongly, when using bank returns in excess of nonfinancial equity returns, as reported in Table A7. See the full discussion in Appendix Section IV. These facts confirm that bank equity returns capture the salient features of banking crises and motivate their use in identifying a broad sample of episodes of banking sector distress, as well as in refining banking crisis chronologies.

\section{Banking crises without panics}

The global financial crisis and Great Recession rekindled a discussion about the role of panics in banking crises. Bernanke (2018), for example, argues that the unusual depth and severity

\footnotetext{
${ }^{14}$ The episodes of $30 \%$ annual bank equity crashes for the U.S. capture the most serious episodes of banking distress, namely in 1907, 1930, 1931, 1937, 1974, 1990, 2007, and 2008.
} 
of the Great Recession was caused by the panics in funding and securitization markets that occurred in the fall of 2008 after the collapse of Lehman Brothers, which led to a sharp contraction in credit supply. He argues that distressed bank and nonfinancial private sector balance sheets alone would not have precipitated such a sharp decline in output. On the other hand, a bank capital crunch may itself lead to a contraction in credit supply that depresses consumption and investment, even without a panic. In this section, we compare the macroeconomic consequences of banking distress with and without panics.

A. Bank equity declines with and without panics

As in Section III, we estimate the response of real GDP and credit-to-GDP to bank equity crashes. However, this time, we interact bank equity crashes with a "panic" indicator. This specification thus allows us to analyze bank equity crashes without panics, bank equity crashes with panics, and panics without bank equity crashes.

To capture episodes of bank distress with and without panics, we systematically go through all $-30 \%$ bank equity crashes, classifying each episode as a "panic" or "non-panic." Table A2 provides a summary of our classification. We research each individual episode, drawing both on standard narrative accounts of crises and also new narrative sources (e.g., newspaper articles, research papers, IMF and governmental reports, first-hand accounts). Extensive historical documentation for each episode regarding the presence or absence of panics can be found in Appendix Section I.B.

Following Calomiris and Gorton (1991) and Gorton and Huang (2003), we define a "panic" as an episode containing (within a \pm 3 -year window) any of the following criteria appearing in narrative accounts: 1) severe and sudden depositor or creditor withdrawals at more than one of a country's largest banks or more than ten smaller banks, that lead these banks to be on the verge of collapse; ${ }^{15}$ 2) severe and sudden strains in interbank lending markets; or 3) severe and sudden

\footnotetext{
${ }^{15}$ Our empirical mapping of panics is based on the definition of Gorton and Huang (2003), who, following Calomiris and Gorton (1991), define a banking panic "as an event in which bank debt holders (depositors) at many or even all banks in the banking system suddenly demand that their banks convert their debt claims into cash (at par) to such an extent that banks cannot jointly honor these demands and suspend convertibility. Note that this definition excludes events in which a single bank faces a run, as a panic is a system-wide phenomenon. Also, cases where depositors seek to withdraw large amounts from the banking system, but banks can honor these withdrawals, are not 'panics, 'although the banking system may shrink significantly" [emphasis added].
} 
foreign-currency capital outflows from the banking sector. ${ }^{16}$ In short, we define panic episodes as an episode when banks experienced sudden salient funding pressures. ${ }^{17}$ Our goal is to err on the side of being overly inclusive in calling episodes a panic and include all potential types of panics. By being overly inclusive, we ensure that the "non-panic distress" episodes that we are most interested in do not include any of these characteristics.

To examine the consequences of banking sector distress by whether they coincide with a panic, we estimate a macroeconomic predictive regression similar to Equation 2, but now interact the $30 \%$ bank equity crash indicator, $1\left[r_{i, t}^{B} \leq-30 \%\right]$, with an indicator for whether there is narrative evidence of a panic. ${ }^{18}$ The specification we estimate is:

$$
\begin{aligned}
\Delta_{\mathrm{h}} y_{i, t+h}=\alpha_{i}^{h} & +\beta_{1}^{h} 1\left[r_{i, t}^{B} \leq-30 \%\right]+\beta_{2}^{h} \text { Panic }_{i, t}+\beta_{3}^{h} 1\left[r_{i, t}^{B} \leq-30 \%\right] \times \text { Panic }_{i, t}+ \\
+ & \Gamma^{\mathrm{h}} X_{i, t}+\varepsilon_{i, t}^{h}
\end{aligned}
$$

As in Equation 2, Equation 3 also includes a 30\% nonfinancial equity crash indicator, along with the standard control variables (country fixed effects, three lags in the bank equity crash, nonfinancial equity crash, panic indicator, and the panic indicator interacted with the equity crash measures, as well as contemporaneous and up to three-year lagged real GDP growth and change in credit-to-GDP). We emphasize that the estimation of Equation 3 does not provide causal evidence on the effects of panics. Instead, it provides the predicted path of output following a panic episode, as well as evidence about whether episodes of non-panic distress are also associated with subsequent downturns. Furthermore, as we define a panic based on narrative information, any selection bias in narrative accounts might inflate the subsequent downturns after panics, but goes against finding substantial downturns after non-panic bank equity crashes.

\footnotetext{
${ }^{16}$ Our broad definition of a panic is motivated by the fact that traditional depositor runs are rare in modern banking crises and we thus want to capture a broad set of definitions of what modern banking panics look like. Furthermore, traditional runs are difficult to observe directly because banks do not generally report their funding status at daily or weekly frequencies, so we need other characteristics, such as sudden strains in interbank lending markets, to help infer the existence of panics among bank creditors.

${ }^{17}$ Empirically it is challenging to disentangle panic runs on solvent but illiquid banks due to strategic uncertainty and runs on insolvent banks. For our purpose, this distinction is not crucial, and we do not attempt it. Artavanis et al. (2019) examine large scale depositor withdrawals in Greece and provide evidence that both fundamental and strategic uncertainty led to sharp increases in depositor withdrawals, with about two-thirds being driven by fundamental uncertainty.

${ }^{18}$ Specifically, the indicator Panic $i, t$ takes the value of 1 just in the year of a crash if there is a panic in any of the surrounding three years. This accounts for the fact that the bank equity crash and the panic may not be exactly contemporaneous. In all other times not near a crash, Panic $c_{i, t}$ takes the value of 1 just in the year of the panic.
} 
Impulse responses of real GDP and bank credit-to-GDP are plotted in Figure 3. The responses represent the impact of: (i) non-panic bank equity crash episodes, $\beta_{1}^{h}$, (109 episodes in the estimation), (ii) panic episodes without a bank equity crash, $\beta_{2}^{h}$, (67 episodes), and (iii) panic episodes with bank equity crashes, $\beta_{1}^{h}+\beta_{2}^{h}+\beta_{3}^{h}$, (34 episodes).

Figure 3 Panel A shows that both panic and non-panic bank equity crashes predict lower subsequent output and credit contraction, though the magnitudes are stronger for panic episodes. The corresponding coefficient estimates at the $t+3$ horizon are reported in Table 3 Panel A. Nonpanic bank equity crashes predict 2.8\% lower output (column 2) and 3.4\% lower credit-to-GDP (column 5) after three years, and the estimates are statistically significant. Episodes of panic bank equity crashes are associated with $4.9 \%$ lower output (column 2, sum of rows 1-3) and 9.1\% lower credit-to-GDP (column 5, sum of rows 1-3) after three years. ${ }^{19}$ While it is not surprising that panic episodes are worse, these estimates suggest that even non-panic bank equity crash episodes are associated with deep recessions and persistently tight credit conditions.

Bank equity crashes allow us to pick up periods of banking sector distress that are not associated with headline events such as a bank panic. However, one concern with Equation 3 is that some of the bank equity crashes may reflect equity market "noise" that is not associated with banking sector losses or other forms of impairment to the banking sector. That is, some of these banking crises without panics may not be banking crises at all, but simply equity market crashes due to sentiment.

To address this concern, we can further refine the set of bank distress episodes into those that also include narrative evidence of widespread bank failures. Observing widespread bank failures is likely a sufficient condition for impairment of the banking system. Widespread bank failures is defined as the failure of a top-5 (by assets) bank or more than five total banks failures above the normal rate of bank failures. Widespread bank failures may still occur in the absence of panics due to orderly bank resolutions, e.g., government-directed purchase-and-assumptions, nationalizations, restructurings, or bank closures, all of which we consider bank failures. We again interact bank equity crash episodes conditional on widespread bank failures with the panic

\footnotetext{
${ }^{19}$ For robustness, Figure A9 plots the full nonlinear specification for bank equity return (similar to Figure 2), but excluding all panic episodes, and Figure A10 estimates a specification with continuous bank equity returns. These results reinforce the finding that bank equity distress outside of panic episodes are also associated with weaker macroeconomic performance.
} 
indicator and re-estimate Equation 3. Figure 3 Panel B presents the results, which are also reported in Table 3 Panel B. Once we condition on episodes of bank failures, non-panic bank equity crash episodes are now as severe as panic episodes. For example, three years after the start of a nonpanic bank equity crash, real GDP is $5.1 \%$ (column 2) below the previous trend, compared to 5.0\% for panic episodes (column 2, sum of rows 1-3). Over the same horizon, non-panic bank equity crashes predict a 7.4 percentage point decline in bank credit-to-GDP (column 5), compared to 8.1 percentages points (column 5 , sum of rows 1-3) for panic episodes. ${ }^{20}$

Figure 3 also analyzes the reverse case: panics without bank equity crashes. The impulse response for these episodes is not statistically or economically different from zero. Thus, panics without bank equity crashes are not associated with any adverse macroeconomic consequences. ${ }^{21}$ One may wonder how we can observe panics without bank equity declines, given that in models of panics described earlier, panics lead to bank failures and therefore to large losses for equity holders. As we explained earlier in footnote 2, this can happen due to various forms of measurement error.

Our finding on the negligible impact of panics without bank equity crashes is consistent with Calomiris (2010), who writes that most pre-Great-Depression panics in the U.S. were driven by relatively small fundamental shocks, which created "temporary confusion" of depositors in these cases but no long-term damage to the banking system or economy. As a result, minor panics without bank equity declines are likely over-represented in narrative chronologies, due to the salience of panics, even though their macroeconomic consequences are mild. On the other hand, bank equity declines without panics may be under-represented in narrative chronologies, due to the difficulties of detection, even though the consequences can be quite dire. The resulting bias

\footnotetext{
${ }^{20}$ One possibility, raised by the model of Gertler and Kiyotaki (2015), is that low output in non-panic bank equity crash episodes may partly reflect anticipated panics that do not materialize. Anticipated panics that do not occur expost can increase bank funding costs, reduce bank net worth, and decrease credit supply in their model. In some settings, explicit government guarantees for distressed banks, including state-owned banks, likely imply that creditors would assign close to zero probability on a panic occurring. In practice, it is difficult to ascertain whether bank creditors assign a positive probability of a panic in our non-panic bank equity crash episodes. Nevertheless, our results show that banking distress can be associated with adverse macroeconomic outcomes without the occurrence of a panic.

${ }^{21}$ Figure A11 addresses the concern that our conservative classification of panics introduces noise that biases down the estimate on the impact of panics without bank equity crashes. Figure A11 performs a similar analysis to Figure 3 , but uses a finer classification of potential panic episodes. We distinguish between episodes with isolated creditor runs (which also include borderline episodes with inconclusive evidence as to whether a panic occurred) versus clear-cut panic episodes. Clear-cut panic episodes have the most severe consequences, but generally only if they are associated with bank equity crashes.
} 
towards salient but inconsequential panics may actually lead standard narrative chronologies to underestimate the costs of banking crises driven by severe solvency concerns, which we will see in Section VI.

\section{B. Examples of non-panic bank distress episodes}

Non-panic bank distress episodes have been quite common historically. From Table A2, we find that among Narrative Crises, $32.8 \%$ of these banking crises do not feature panics. Figure A12 in the Appendix plots the frequency of banking crisis episodes (using our BVX Crisis List introduced in Section VI) which are not associated with panics for each decade in our sample since the 1870 s. In the $19^{\text {th }}$ century, virtually all banking crises featured banking panics. By the interwar period, some crises did not involve banking panics, though most crises were associated with panics. In the post-war era, especially in the post-Bretton-Woods period, the frequency of crises without panics increased. This increase over time may reflect the expanded role of government in financial regulation, including the gradual adoption of central banks with lender of last resort facilities, deposit insurance, and expanded fiscal capacity for regulatory forbearance. The $20^{\text {th }}$ century also witnessed a gradual increase in banking sector leverage (Jordà, Richter, Schularick, and Taylor 2017), which has increased bank vulnerability to losses.

We highlight several prominent episodes of Narrative Crises that do not feature panics. Our first example of non-panic bank distress is the initial stages of Japan's recent banking crisis (19911996). In this phase of Japan's crisis, most of the major banks were thought to be near insolvency following the crash in the Japanese real estate and stock market, but significant regulatory forbearance and perceptions of strong government guarantees to creditors forestalled a creditor panic. In general, strong government guarantees characterize many episodes of "non-panic bank distress". This situation lasted until the fall of 1997, when the collapse of two major securities firms and the Hokkaido Takushoku Bank led interbank markets to seize up, ushering in the panic phase of the crisis (1997-98). The severe declines in bank equity experienced by Japanese banks also translated into contractions in lending and construction activity in U.S. markets with large penetration by subsidiaries of Japanese banks, highlighting that a cutback in credit supply had important real effects in this crisis (Peek and Rosengren 2000). 
Other examples of Narrative Crises that did not feature panics include the following wellknown historical banking crises: Sweden in 1921-1926, Spain in 1977-1982, Denmark in 19871992, and the U.S. in 1990-1992. For example, a number of studies argue that bank losses contributed to the severity of the 1990-91 recession in the U.S., despite the absence of panics, especially in the northeast region (Syron 1991, Bernanke and Lown 1991, Peek and Rosengren 1992, and Mian, Sufi, and Verner 2019). ${ }^{22}$

At the same time, we identify many other episodes of non-panic bank distress that were not previously identified by narrative-based approaches, including: ${ }^{23}$

- Canada during the Great Depression. Despite the lack of a banking panic and only a single bank failure (Weyburn Security Bank), Kryzanowski and Roberts (1993) argue that the large and widespread bank losses in Canada, as reflected by the large fall in bank stock prices, in part explain the extreme macroeconomic severity of the Great Depression in Canada. ${ }^{24}$

- 1973-75: Many countries experienced bank distress during the global downturn of 197375, including Australia, Finland, France, Greece, Hong Kong, Ireland, Italy, Singapore, Switzerland, Turkey, and the U.S., all of which saw large drops in bank equity, both in absolute terms and relative to nonfinancial equity. ${ }^{25,26}$ The recessions in these countries were relatively deep and prolonged, compared to previous postwar recessions.

\footnotetext{
${ }^{22}$ For example, writing about the 1990-91 recession, Syron (1991) argues that "[i]n substantial measure, this period of tight credit is the result of a loss of bank capital, rather than a loss of deposits" (p. 4).

${ }^{23}$ Though it is not included on our list of non-panic bank equity crash episodes, because the bank equity decline is less than $30 \%$ in magnitude, the U.S. in 1920-21, in which strong monetary contraction induced waves of bank failures and a large aggregate credit contraction, is an important example too.

${ }^{24}$ Kryzanowski and Roberts (1993) note that the large Canadian banks "were insolvent at market values and remained in business only due to the forbearance of regulators coupled with an implicit guarantee of all deposit", both policies being held over from the previous Canadian banking crisis of 1923. They report that the largest Canadian bank at the time, the Bank of Montreal, had estimated nonperforming loans in excess of $40 \%$.

${ }^{25}$ Among these non-panic episodes, the banking problems were perhaps the most severe in Australia, which saw a large real estate bust and numerous failures of building societies and small banks between 1974 and 1979 (Fitz-Gibbon and Gizycki, 2001). In Western Europe, countries faced balance-of-payment crises, which impacted the banking sector especially through large foreign exchange losses at banks and tight Eurodollar funding (Coombs, 1973). In particular, Germany's Herstatt Bank failed in 1974, and Germany's Westdeutsche Landesbank and Switzerland's UBS suffered large losses in foreign exchange markets (Schwartz, 1987). In Singapore, the Chung Khiaw Bank, then part of United Overseas Bank, was rumored to be close to bankruptcy.

${ }^{26}$ In the U.S., in particular, there were large aggregate bank losses, widespread symptoms of financial distress, and several prominent failures of large regional banks. Doyran (2016) writes: "Although bank profits subsided in 1974 because of high interest rates and foreign competition, US banks were particularly hard hit by bad loan portfolios, poor regulatory oversight over foreign exchange transactions, inadequate capital (high loan/capital ratio), deficient
} 
- 2002-03: Several countries, including Germany, Greece, Israel, Italy, Japan, and Portugal, saw large drops in bank equity, both in absolute terms and relative to nonfinancial equity. In Germany, for example, according to the IMF's financial stability report in 2003, three out of the four largest German private commercial banks suffered major losses in 2002, and a number of small and medium-sized institutions had to be merged, closed by the regulator, or assisted, due to serious difficulties. In Israel, banks suffered large credit losses, with the collapse of Trade Bank and large losses at Discount Bank. In Japan, still recovering from the banking crisis of the 1990s, new problem loans were disclosed across the banking sector; in particular, the government injected 2 trillion yen into Resona Bank, one of Japan's largest banks, which was effectively insolvent, and nationalized Ashikaga Bank, a large regional bank.

\section{Quiet crises}

In this subsection, we ask whether large bank equity declines predict subsequent output and credit contractions, even in the absence of any narrative evidence of either banking panics or widespread bank failures. That is, are there "quiet" episodes of bank distress with negative macroeconomic consequences? During such "quiet" crises, several factors may forestall bank creditors from running on a bank, including government intervention that is kept hidden and the absence of other bank failures, which may give the impression to creditors that the health of the banking sector is sound. However, any banks losses experienced by a bank may still lead to tighter credit conditions. We re-estimate Equation 1, but now exclude country-year observations within a \pm 3 -year window around episodes with either a panic or widespread bank failure in Table A2. As before, we control for nonfinancial equity return indicators, along with the standard control variables.

Figure 4 plots impulse responses from local projections for future real GDP and bank credit to GDP. As can be seen in this non-parametric specification, the magnitudes of the real GDP

\footnotetext{
internal controls and audit procedures, and aggressive expansion through the use of short-term borrowed funds, especially Eurodollar funds, money market CDs and federal funds. In early 1974, a tightened monetary policy surprised banks expecting eased interest rates. This led to short-term borrowing for large real estate projects as many large banks borrowed billions on a daily basis to collateralize short-term loans. When higher interest rates were announced, they suffered enormous losses. The concern over the effects of financial instability increased greatly as regulators reported substantial increases in the number of "problem banks' under their supervision."
} 
decline are nearly as large excluding episodes with panics or bank failures as they are in the full sample (Figure 2). ${ }^{27}$ Thus, the predictive content of bank equity declines is not simply driven by episodes with panics or bank failures and reinforces the result that episodes of non-panic bank distress are associated with adverse macroeconomic consequences. Moreover, it suggests that banking sector distress and credit supply contraction play an important role in business cycles more generally.

\section{Relative timing of bank equity declines, panics, and other financial market indicators}

The previous section showed that panics are not necessary for bank equity distress to be associated with output and credit contractions. However, panics can substantially amplify the consequences of banking sector distress. In this section, we examine the timing of bank equity declines relative to the start of panics and financial market indicators. To do this, we use monthly data around banking crises on the BVX Crisis List, a list of clear-cut crisis episodes fully described in Section VI, to provide an in-sample analysis of the relative timing of bank equity declines, panics, credit spread spikes, and nonfinancial equity declines. This analysis also illustrates how bank equity returns can be useful in providing information on the timing and proximate causes of banking crises. Monthly data tell us about the turning points of crises and the dynamics of how crises evolve, as understood in real-time by equity and debt investors. This higher-frequency information allows us to show that large bank equity declines usually precede panics and credit spread increases during these clear-cut banking crisis episodes.

The U.S. 2007-8 banking crisis provides a vivid illustration of the key results, so we start with this case study before showing the results for a broad sample of crises. Figure 5 shows that, for the 2007-8 U.S. crisis, bank equity declined substantially before the panic phase of the crisis, which we date as starting in September 2008. Bank equity also detected the impending crisis before credit spreads and nonfinancial equity. Bank equity peaked in January 2007, ten months before the nonfinancial index peak in October 2007; similarly, bank equity cumulatively fell $30 \%$ by February 2008, while nonfinancial equity did not do the same until September 2008. Meanwhile,

\footnotetext{
${ }^{27}$ Similarly, Table A8 show no difference between the predictive content of bank equity crashes in Narrative Crisis episodes and outside them.
} 
corporate spreads (the AAA-Govt and BAA-AAA spreads) and interbank lending spreads (the LIBOR-OIS spread) relative to baseline levels remained under one percentage point until the panic phase of the crisis in September 2008, a full 21 months after bank equity had started declining. ${ }^{28}$ We will show in this section that these patterns also hold in other historical episodes on the BVX Crisis List.

\section{A. Bank equity crashes and panics}

Figure 6 presents the dynamics of bank equity returns, relative to other financial market measures, systematically across all crises on the BVX Crisis List. ${ }^{29}$ We focus on a three-year window around the crises on the BVX Crisis List and compute the average evolution of equity indexes and credit spreads. Time 0 in event time is defined as January of the BVX crisis year, and equity indexes (measured on the left axis) and credit spread measures (right axis) are normalized to zero in this month. In the same figure, we plot the frequency distribution of panics, conditional on panics occurring, to provide a visual sense of whether panics tend to occur before or after large bank equity declines. ${ }^{30}$ Panel A in Figure 6 presents the average dynamics for the full sample, and the remaining panels present results for various subsamples.

We start by focusing on the relative timing of bank equity declines and panics. The blue line in Figure 6 plots the average dynamics of bank equity returns, and the orange line represents a frequency plot of the first panic month, with the area under this curve normalized to one. Figure 6 shows that on average bank equity falls substantially before the panic phase of the crisis. Panics tend to occur during the crisis year (months 0 to 11 in event time), while bank equity generally peaks and begins declining in the year prior to when the crisis is dated.

\footnotetext{
${ }^{28}$ Equity and bond prices for Lehman Brothers, whose failure precipitated the panic phase of the 2007-08 crisis, display similar dynamics. Lehman Brothers' stock price saw a gradual but large decline of $67 \%$ relative to the S\&P 500 from its peak in January 2008 to the week before its bankruptcy in September 2008. In contrast, returns on Lehman bonds were much more stable throughout the spring and summer of 2008. Relative to January 2008, the cumulative abnormal return on Lehman bonds was only $-3 \%$ one week before its bankruptcy. Lehman bonds then fell sharply in the week leading up to its bankruptcy (Denison, Fleming, and Sarkar 2019).

${ }^{29}$ Figure A13 presents the same results across crises on the Narrative Crisis list, demonstrating that these results are robust to alternative banking crisis lists.

${ }^{30}$ The starting month of each panic, according to narrative accounts, is reported in Table A2. Appendix I.B links to extensive historical documentation on the onset month of panics.
} 
Table 4 Panel A analyzes the timing of bank equity declines and panics more formally. Column 1 computes the average number of months between the "bank equity crash" (defined here as when bank equity has declined cumulatively by $30 \%$ from its previous peak) and the month of the panic. For example, in the U.S. in 2008, the bank equity crash occurs in February 2008, while the panic occurs in September 2008, giving this episode a value of seven months. On average across BVX Crisis List episodes with a panic, the panic occurs 7.5 months after the bank equity crash. Column 1 also reveals that in 74\% (69 out of 93) of crises with panics for which we have data, the bank equity crash strictly precedes the panic. In contrast, panics occur before bank equity crashes in only $20 \%$ of cases (19 out of 93 ). ${ }^{31}$ This difference is statistically significant based on a $p$-value calculated under the null hypothesis that the event "bank equity crash happens before the panic" is Bernoulli-distributed with parameter $0.50 .{ }^{32}$

Figure 7 Panel A presents the full distribution of bank equity declines from the previous peak to the month just prior to the panic for the sample of banking crises with panics. On average across BVX Crisis List episodes, bank equity declines by $36 \%$ from the peak to the month strictly prior to the panic. Figure 7 Panel B plots the distribution of bank equity declines at the month strictly prior to the panic expressed as a percent of its total eventual peak-to-trough decline. On average across banking crises with panics, bank equity has sustained $55 \%$ of its total eventual peak-to-trough decline before the panic occurs.

Overall, the evidence shows that panics, when they occur, tend to occur substantially after the crisis has been detected by bank equity and large losses have been realized by bank equity investors. This pattern therefore implies that a non-trivial proportion of bank losses are already present at the early stages of a crisis, before the panic, rather than being caused by the panic. Panics thus tend to represent the final, most extreme phase of a crisis that arises after substantial losses have been realized. This general pattern lends support to the second group of theories discussed in

\footnotetext{
${ }^{31}$ Gorton (1988) finds that panics in the U.S. National Banking Era (1863-1914) typically occurred a few months after NBER business cycle peaks. He argues these panics were due to systematic responses by depositors to changing perceptions of risk, based on the arrival of new information about a coming recession and resulting loan losses. Calomiris and Gorton (1991) also focus on panics in the U.S. National Banking Era and find that panics were preceded by sharp declines in stock prices.

${ }^{32}$ Appendix Table A9 shows these results are robust to using the sample of episodes on the Narrative Crisis List, demonstrating that the result is not specific to the BVX Crisis List.
} 
Section I.A, i.e., Goldstein and Pauzner (2005) and He and Xiong (2012), which highlights panic bank runs as an amplification mechanism of initial negative fundamental shocks.

Do bank equity declines pick up crises before or after the crisis dates from previous narrative approaches? Table 4 Panel A shows that bank equity crashes pick up banking crises 3.2 months before the Reinhart and Rogoff (2009) dates and 2.9 months before the Narrative Crisis dates (defined as the earliest date across the six narrative approaches). This calculation uses January as the starting month of each Narrative Crisis, as narrative chronologies usually only provide the year of the crisis, so this estimate is conservative. Given that narrative chronologies often date crises based on the year when the panic starts, this provides further support for the result that bank equity declines precede panics. It also suggests that narrative accounts tend to date crises late. This result is consistent with Boyd, De Nicolo, and Rodionova (2019), who show that bank lending contracts before crises are dated by narrative approaches.

B. Bank equity crashes and credit spread spikes

What is the relationship between bank equity declines and credit spread increases? As we discussed earlier, policy makers tend to use disruptions in credit-markets as indicators of panics by bank creditors. Credit spread spikes serve as our proxy of disruptions in credit markets. Figure 6 shows that, in all subsamples of the data, bank equity falls by large amounts well ahead of the credit spread increases. Both interbank lending spreads (the green line) and corporate credit spreads (the black line) increase after the start of the crisis, while bank equity falls prior to the year of the crisis. The spike in credit spreads tends to coincide with the occurrence of panics (the orange line), confirming that credit spread spikes proxy for the occurrence of panics. Because credit spreads are only available for a smaller subset of crises, Panel B in Figure 6 presents the same event study for a consistent sample with non-missing equity measures and bank credit spreads. Panel B confirms that the differences in the timing of bank equity declines and credit spread spikes are not driven by different underlying samples. The fact that bank equity falls first before the spike in credit spreads is consistent with our earlier discussion that credit-market instruments tend to have lower information sensitivity than bank equity because equity holders take first losses while creditors suffer losses only when banks approach default. 
Table 5 reinforces the evidence that bank equity tends to lead credit spreads by showing the distribution of credit spread increases conditional on bank equity falling by a certain amount. For example, Panel A shows that, by examining BVX Crisis List episodes, when bank equity first falls by more than $30 \%$ (row 3), the median credit spread increase is only 52 basis points (bps). In more than $20 \%$ of cases, bank credit spreads have not increased at all at this point. Only in $10 \%$ of cases has the bank credit spread increased by more than 1 percentage point. For reference, the median trough-to-peak bank credit spread spike across BVX Crisis List episodes is 2.5 percentage points.

Panel B in Table 5 presents the results for corporate credit spreads, rather than bank credit spreads. Similar to the results in Panel A, when bank equity first falls by more than $30 \%$ (row 3), the median corporate credit spread increase is only $2 \mathrm{bps}$, and in over $40 \%$ of cases corporate credit spreads have not increased at all. For reference, the median trough-to-peak corporate credit spread spike across BVX Crisis List episodes is $1.7 \%{ }^{33}$

Taken together, the analysis in this subsection shows that bank equity declines tend to precede credit spread spikes, which motivates policy makers to pay more attention to bank equity declines in assessing the developing risk of an emerging banking crisis.

C. Bank and nonfinancial equity crashes

Figure 6 also shows that bank equity tends to peak and decline earlier that nonfinancial equity during banking crises. Column 1 in Table 4 Panel B confirms this result by showing that bank equity crashes precede similarly defined nonfinancial equity crashes by a statistically significant average of 1.94 months. Similarly, Column 2 in Table 4 Panel B shows that the bank equity index peaks 1.37 months before the nonfinancials index peaks. The fact that bank equity leads nonfinancial equity in declining suggests that many banking crises originate with shocks to specific segments of the economy to which banks have significant exposures (e.g., subprime exposure in 2008), rather than with broad macroeconomic shocks affecting the entire nonfinancial

\footnotetext{
${ }^{33}$ As a robustness check, Table 4 Panel A compares the timing of $30 \%$ bank equity crashes to the timing of credit spreads spikes. We record a credit spread "spike" as the first month in which credit spreads increase at least 1 percentage point above their pre-crisis average levels. Since a 1 percentage point increase is somewhat arbitrary, we present this evidence mainly as robustness analysis confirming the result in Figure 6. Nevertheless, Table 4 Panel A shows that $30 \%$ bank equity crashes detect the crisis 3.4 months before a $1 \%$ spike in bank credit spreads (column 5 ) and 4.1 months before a $1 \%$ spike in corporate credit spreads (column 7).
} 
sector. Interestingly, Panels $\mathrm{C}$ and $\mathrm{D}$ in Figure 6 show that the pattern that bank equity leads nonfinancial equities holds mainly for post-WWII crises and advanced economies - and is often the opposite for prewar crises or emerging economies (see also Table A10). This suggests that the initial causes of banking crises may have changed over time. More recent crises in advanced economies tend to start with distress to banks exposed to specific segments of the economy, such as real estate. In contrast, prewar banking crises may have been the result of broader macroeconomic shocks that only later translated into bank equity losses.

Figure 6 Panel A also reveals several additional new facts about bank equity around banking crises. First, bank equity falls substantially more than nonfinancial equity conditional on a BVX banking crisis, even though bank equity has an unconditional market beta of 0.8 in our sample. Second, bank equity declines are "permanent," in the sense that they do not recover postcrisis, presumably reflecting permanent credit losses. In contrast, nonfinancial equity gradually recovers after the crisis. Third, bank equity declines tend to unfold gradually over several years, with an average peak-to-trough duration of 27.2 months (also see column 3 in Table 4 Panel B). This slow decline could potentially reflect a behavioral bias of overoptimistic investors initially underestimating the true depth of the crisis (e.g., Gennaioli and Shleifer, 2018), or, in a rational framework, the presence of informational frictions making it difficult for investors in real-time to assess the extent of bank losses.

\section{Forgotten crises and the BVX Crisis List}

While bank equity declines allow us to screen out a relatively complete set of episodes of banking distress with and without narrative evidence of panics, some bank equity crashes may be due to equity market sentiment unrelated to banking distress. For some in-sample studies of banking crises, such as the timing analysis on specific events in the previous section, it is useful to create a chronology of clear-cut banking crisis episodes that are free of false positives, albeit at the expense of potentially selecting more severe episodes. This section provides details on constructing the BVX Crisis List, which uses bank equity returns along with narrative information on crises to refine the existing chronology of banking crises in a systematic way. There is obviously no single correct definition of a banking crisis or list of them, but our goal is to provide one possible 
construction of clear-cut crisis episodes based on systematic criteria emphasizing bank equity losses, bank failures, and panics.

To construct the BVX Crisis List, we actually construct two chronologies. The first is a chronology of "bank equity crises." We build this list by first screening for cumulative 30\% declines in bank equity, which may indicate potential banking crises, then only including the subset of these with narrative evidence of widespread bank failures. Widespread bank failures is defined as the failure of a top-5 (by assets) bank or more than five total banks failures above the normal rate of bank failures. ${ }^{34}$ The second is a chronology of "panic banking crises," based on the list of panics from Table A2. The union of these two sets is the BVX Crisis List, which we present in Table 6. The BVX Crisis List distinguishes between crises involving bank equity losses and those involving panics (or both), emphasizing that banking crises take various forms. We date the start of each crisis as the year in which the bank equity index first falls more than $30 \%$ from its previous peak. (In cases in which there is no cumulative 30\% decline, we use the Narrative Crisis date.) We also list the bank equity peak-to-trough real total return in Table 6 (i.e. the cumulative return from the previous peak before the crisis to the subsequent trough, based on annual data) as a measure of the severity of each banking crisis. ${ }^{35,36}$

Our new bank equity data allow us to uncover 27 newly-identified crises (meaning they are not Narrative Crisis episodes), which are marked with an asterisk in Table 6. While some of them are newly-identified just because they are very recent episodes (e.g., the 2011 Eurozone crises), others are "forgotten" historical crises (meaning that they do not appear to have been known by the authors of the Narrative Crisis lists), such as the following examples ${ }^{37}$ :

\footnotetext{
${ }^{34}$ See Appendix Section I.B for a more detailed definition of "widespread bank failure" and for historical documentation of bank failures for each episode. A "bank failure" is defined broadly to include forced mergers, restructurings, government equity injections, and nationalizations of nearly failing banks.

${ }^{35}$ We also revise the starting years of all bank crises (see Table A12, Panel A) to correspond with the initial year of $30 \%$ bank stocks crashes. Of course, there are reasons why the narrative accounts date the starting year when they do. With the new dates, our goal is simply to offer additional and alternative information about when markets first recognized the bank equity losses. See Table A2 for a comparison with the Narrative Crisis dates, which in most cases are very similar. Also, on the BVX Crisis List, we occasionally combined several pairs of episodes occurring close together in time (see Table A12 Panel B), when it seems more appropriate to consider them as a single crisis (i.e. when bank equity returns did not show two separate declines and when the narrative evidence on bank failures conveyed a continuous sequence of banking distress across time, not clustered into two phases).

${ }^{36}$ In Appendix Section VI.C and Figure A15, we use these crisis severity measures to analyze episodes from the global Great Depression, in which there is some debate about which countries experienced severe banking crises.

${ }^{37}$ They have not been forgotten by all banking crisis historians, as we collect narrative evidence on each of these episodes, as presented here.
} 
- Belgium in 1876. As reported by Grossman (2010): "the boom in Belgium after the FrancoPrussian war led to the establishment of new banks. Several of these failed when the international crisis of 1873 arrived in Belgium. A few smaller banks went into receivership, and the larger Banque de Belgique, Banque de Bruxelles, and Banque Central Anversoise had to be re-organized. Durviaux (1947) calls this a serious crisis, while Chelpner (1943) suggests it may have been less serious." In this episode, the bank equity total return index declined by $37.4 \%$.

- Japan in 1922. This episode is distinct from the Japanese banking crises of 1920 and 1923. Shizume (2012) writes: "Ishii Corporation, a lumber company engaged in speculative activities, went bankrupt at the end of February 1922, triggering bank runs in Kochi Prefecture (in south-western part of Japan) and Kansai region (Osaka, Kyoto and their environs). Then, from October through December 1922, bank runs spread far across the country, from Kyushu (the westernmost part of Japan) through Kanto (Tokyo and its environs in eastern Japan)... The BOJ extended 'special loans' to 20 banks from December 1922 to April 1923." In this episode, the bank equity total return index declined by $40.5 \%$.

Table A11 lists the "removed banking crises", which include 53 episodes from the Narrative Crisis list that are not considered banking crises on the BVX Crisis List. Of the "removed banking crises," we mark a subset of them with an asterisk which we consider "spurious banking crises," defined as episodes which have few or no characteristics typically associated with banking crises and are likely the result of clear-cut typographical or historical errors on one of the Narrative Crisis chronologies. ${ }^{38}$ As a concrete example, our BVX Crisis List omits Germany in 1977. For this episode, Reinhart and Rogoff (2009) simply report that "Giro institutions faced problems," though we could not find any independent verification from contemporaneous German- or English-language newspaper accounts of any unusual problems affecting the banking sector at the time, and the peak-to-trough bank equity decline was small $(-11.7 \%)$. These errors are often

\footnotetext{
${ }^{38}$ The documentation linked to Appendix I.B traces many of the sources of these errors. One problem inherent in many older accounts of crises is that the terms "financial crisis" and "panic" are used variously to describe: monetary crises, currency crises, sovereign debt crises, or even just stock market crashes, without being clear about what they are describing. These other types of financial crises often get conflated with banking crises in secondary sources that cite these original historical accounts.
} 
perpetuated across studies that build on previous chronologies. ${ }^{39}$ Bank equity declines thus provide an objective criterion to screen crisis episodes and remove episodes that feature little evidence of any of the features commonly associated with banking crises.

Table 7 summarizes the properties of the BVX Crisis List. Column 1 shows that the average peak-to-trough bank equity decline in BVX Crises is $46.2 \%$ and the average peak-to-trough decline in real GDP is $5.5 \%$. Crises with a bank equity decline of greater than $30 \%$ display even larger declines in real GDP (column 2). Columns 3 and 4 in Table 7 also provide summary statistics on the newly-uncovered crises and removed crises. Column 3 shows that the newly-identified crises display larger declines in bank equity and real GDP compared to the average for all episodes on the BVX Crisis List (column 1), suggesting that these added episodes are worthy of being considered crises. In contrast, column 4 shows that the removed episodes are considerably less severe, suggesting that some of these episodes may indeed be "spurious crises".

To assess potential biases of the narrative lists, we compare the BVX Crisis List with various narrative crisis lists. Appendix Figure A16 compares the macroeconomic consequences of BVX Crisis List episodes with those from Reinhart and Rogoff (2009) and Laeven and Valencia (2013). Appendix Table A13 likewise compares along various banking crisis dimensions. Compared to Reinhart and Rogoff's list of banking crises, for example, we find the consequences of the BVX Crisis List episodes are actually slightly more severe in terms of the decline in real GDP and credit-to-GDP. ${ }^{40}$ These results are discussed in detail in Appendix Section VI.D. The fact

\footnotetext{
${ }^{39}$ For example, Reinhart and Rogoff (2009) call Italy in 1935 a crisis, because Bordo et al. (2001) consider it a crisis, because, in turn, Bernanke and James (1991) consider it a crisis, though it is unlikely that any banking crisis, however defined, started in 1935. In fact, the main banking crisis in Italy erupted in 1930 and by 1935 was largely resolved (the entire banking sector had largely been nationalized). According to Italian government records, the only bank to fail in 1935 was Credito Marittimo, which had been nationalized years earlier and was only finally liquidated by the government in 1935.

40 Table A13 Panel B performs the same comparison with Laeven and Valencia's crisis chronology (on the same time sample, 1970-2012). On average, BVX crisis episodes are slightly less severe than Laeven and Valencia's, perhaps because Laeven and Valencia only identify crises that are serious enough to warrant several forms of major government intervention. In unreported results we find that the BVX Crisis List episodes are more severe than Schularick and Taylor's (when compared on their sample of 14 countries) and Bordo et al.'s. As an alternative way to compare the accuracy of the BVX Crisis List and previous chronologies, Table A14 shows that a variety of crises indicators (real GDP growth, bank equity returns, and credit growth) line up more closely with the BVX Crisis List than with crises identified by Reinhart and Rogoff (2009) and Laeven and Valencia (2013).
} 
that the BVX Crisis List is on average more severe may be, in large part, due to eliminating many spurious crises from their list. ${ }^{41}$

\section{Conclusion}

By constructing a new historical dataset of bank equity returns for 46 countries going back to 1870 , we document that large bank equity declines are a strong predictor of lower subsequent GDP growth and bank credit-to-GDP, even after controlling for nonfinancial equity returns. The relation between bank equity returns and subsequent macroeconomic outcomes is highly nonlinear, showing that bank equity is particularly informative about severe negative macroeconomic events involving a decline in intermediated credit. The informativeness of large declines in bank equity allows us to map out a broader sample of crises, including banking crises with and without panics. By separately examining these subsamples of crisis episodes, we find that while large bank equity declines coupled with narrative evidence of panics are followed by the most severe macroeconomic downturns, episodes of non-panic banking distress also translate into prolonged output gaps and non-trivial credit contractions. Moreover, panics, when they do occur, tend to come after substantial bank equity declines, reflecting the fact that large current and expected future losses have already been realized by equity investors.

Our results suggest that the defining feature of a banking crisis is a bank capital crunch. These capital crunches often, though not always, lead bank creditors to run on bank debt, especially once large current and expected future losses have been realized and banks appear sufficiently undercapitalized. However, even when panics are averted, for example by implicit or explicit guarantees, an undercapitalized banking system is still unable to adequately service the economy. Thus, it is important for regulators to focus on bank capital adequacy during emerging crises, in addition to preventing funding pressures and outright panics. Furthermore, while credit spreads directly capture panic-like disruptions in credit markets, bank equity, by being more informationsensitive to banking sector health, may give more information about the state of the banking sector in the early stages of the crisis. Our evidence suggests that simple bank equity measures, in addition

\footnotetext{
${ }^{41}$ On the BVX Crisis List, we removed 44 events from Reinhart and Rogoff's list, and these removed events have an average GDP decline of $-2.1 \%$. Thus, this small average GDP decline from removed crises likely biases down the average severity of Reinhart and Rogoff's crises.
} 
to credit expansion measures, provide a useful real-time barometer of the health of the banking sector.

As a final caveat, we emphasize that while our results provide new insights into the roles of bank losses and panics, we cannot causally identify the role of bank losses and panics in depressing bank lending and output. Our episodes of large bank equity declines capture broad episodes of bank distress and output contraction, but these declines may in part be due to weak corporate and household balance sheets, beyond banking sector distress itself. We look forward to future work that attempts to disentangle the causal roles of the bank lending channel, banking panics, and non-financial balance sheet distress.

\section{References}

Admati, Anat, and Martin Hellwig. The Bankers' New Clothes: What's Wrong with Banking and What to Do about It. Princeton University Press, 2014.

Adrian, Tobias, Nina Boyarchenko, and Domenico Giannone. "Vulnerable Growth." American Economic Review 109, no. 4 (2019): 1263-89.

Allen, Franklin, and Douglas Gale. "Optimal Financial Crises." Journal of Finance 53, no. 4 (1998): 1245-1284.

Amiti, Mary, and David Weinstein. "Exports and Financial Shocks." Quarterly Journal of Economics 126, no. 4 (2011): 1841-1877.

Artavanis, Nikolaos, Daniel Paravisini, Claudia Robles-Garcia, Amit Seru, and Margarita Tsoutsoura. "Deposit Withdrawals." Working paper, 2019.

Baron, Matthew, and Wei Xiong. "Credit Expansion and Neglected Crash Risk." Quarterly Journal of Economics 132, no. 2 (2017): 713-764.

Bernanke, Ben, and Cara Lown. "The Credit Crunch.” Brookings Papers on Economic Activity 1991, no. 2 (1991): 205-247.

Bernanke, Ben, and Harold James. "The Gold Standard, Deflation, and Financial Crisis in the Great Depression: An International Comparison." In Financial Markets and Financial Crises, pp. 33-68. University of Chicago Press, 1991.

Bernanke, Ben. "The Real Effects of the Financial Crisis." Brookings Papers on Economic Activity 20 (2018).

Bordalo, Pedro, Nicola Gennaioli, and Andrei Shleifer. "Diagnostic Expectations and Credit Cycles." Journal of Finance 73, no. 1 (2018): 199-227. 
Bordo, Michael, Barry Eichengreen, Daniela Klingebiel, and Maria Soledad Martinez-Peria. "Is the Crisis Problem Growing More Severe?” Economic Policy 16, no. 32 (2001): 52-82.

Boyd, John, Gianni De Nicolo, and Tatiana Rodionova. "Banking Crises and Crisis Dating: Disentangling Shocks and Policy Responses.” Journal of Financial Stability 41 (2019): 45-54.

Brunnermeier, Markus, and Yuliy Sannikov. "A Macroeconomic Model with a Financial Sector." American Economic Review 104, no. 2 (2014): 379-421.

Calomiris, Charles. "Banking Crises Yesterday and Today." Financial History Review 17, no. 1 (2010): 3-12.

Calomiris, Charles, and Charles Kahn. "The Role of Demandable Debt in Structuring Optimal Banking Arrangements.” American Economic Review 81, no. 3 (1991): 497-513.

Calomiris, Charles, and Gary Gorton. "The Origins of Banking Panics: Models, Facts, and Bank Regulation.” In Financial Markets and Financial Crises, pp. 109-174. University of Chicago Press, 1991.

Calomiris, Charles, and Joseph Mason. "Fundamentals, panics, and bank distress during the Depression." American Economic Review 93, no. 5 (2003): 1615-1647.

Caprio, Gerard, and Daniela Klingebiel. "Bank Insolvency: Bad Luck, Bad Policy, or Bad Banking?" In Annual World Bank Conference on Development Economics, vol. 79, World Bank publication (1996).

Caprio, Gerard, and Daniela Klingebiel. "Episodes of Systemic and Borderline Banking Crises." In Managing the Real and Fiscal Effects of Banking Crises, World Bank publication (2003): 31-49.

Chari, Varadarajan, and Ravi Jagannathan. "Banking Panics, Information, and Rational Expectations Equilibrium.” Journal of Finance 43, no. 3 (1988): 749-761.

Chelpner, B. Belgian Banking and Banking Theory. Washington: Brookings Institution, 1943.

Chodorow-Reich, Gabriel. "The Employment Effects of Credit Market Disruptions: Firm-Level Evidence from the 2008-9 Financial Crisis." Quarterly Journal of Economics 129, no. 1 (2014): 1-59.

Coombs, Charles. "Treasury and Federal Reserve Foreign Exchange Operations." Monthly Review (New York Fed) 55 (1973): 47-65.

Covitz, Daniel, Nellie Liang, and Gustavo Suarez. "The Evolution of a Financial Crisis: Collapse of the Asset-Backed Commercial Paper Market." Journal of Finance 68, no. 3 (2013): 815848 .

Dang, Tri Vi, Gorton, Gary and Holmström, Bengt. "The Information View of Financial Crises." Annual Review of Financial Economics, forthcoming (2019). 
Demirgüç-Kunt, Asli, and Enrica Detragiache. "Cross-Country Empirical Studies of Systemic Bank Distress: A Survey.” National Institute Economic Review 192, no. 1 (2005): 68-83.

Denison, Erin, Michael Fleming, and Asani Sarkar. “The Indirect Costs of Lehman's Bankruptcy”. Liberty Street Economics blog, Federal Reserve Bank of New York, 2019. https://ibertystreeteconomics.newyorkfed.org/2019/01/the-indirect-costs-of-lehmansbankruptcy.html

Diamond, Douglas, and Philip Dybvig. "Bank Runs, Deposit Insurance, and Liquidity." Journal of Political Economy 91, no. 3 (1983): 401-419.

Doyran, Mine Aysen. Financial Crisis Management and the Pursuit of Power: American Preeminence and the Credit Crunch. Routledge, 2016.

Driscoll, John, and Aart Kraay. "Consistent Covariance Matrix Estimation with Spatially Dependent Panel Data." Review of Economics and Statistics 80, no. 4 (1998): 549-560.

Durviaux, Roland. La Banque Mixte: Origine et Soutien de l'Expansion Économique de la Belgique. E. Bruylant, 1947.

Fitz-Gibbon, Bryan, and Marianne Gizycki. "A History of Last-Resort Lending and Other Support for Troubled Financial Institutions in Australia." Reserve Bank of Australia Research Discussion Paper, 2001.

Friedman, Milton, and Anna Schwartz. A Monetary History of the US 1867-1960. Princeton University Press, 1963.

Gennaioli, Nicola, and Andrei Shleifer. A Crisis of Beliefs: Investor Psychology and Financial Fragility. Princeton University Press, 2018.

Gertler, Mark, and Nobuhiro Kiyotaki. "Financial Intermediation and Credit Policy in Business Cycle Analysis.” In Handbook of Monetary Economics, vol. 3, pp. 547-599. Elsevier, 2010.

Gertler, Mark, and Nobuhiro Kiyotaki. "Banking, Liquidity, and Bank Runs in an Infinite Horizon Economy." American Economic Review 105, no. 7 (2015): 2011-43.

Goldstein, Itay, and Ady Pauzner. "Demand-Deposit Contracts and the Probability of Bank Runs." Journal of Finance 60, no. 3 (2005): 1293-1327.

Gorton, Gary. "Banking Panics and Business Cycles." Oxford Economic Papers 40, no. 4 (1988): 751-781.

Gorton, Gary. "The Panic of 2007." NBER Working Paper No. w14358. National Bureau of Economic Research, 2008. https://www.nber.org/papers/w14358

Gorton, Gary. "Some Reflections on the Recent Financial Crisis." Trade, Globalization and Development. pp. 161-184. Springer, 2014.

Gorton, Gary, and George Pennacchi. "Financial Intermediaries and Liquidity Creation." Journal of Finance 45, no. 1 (1990): 49-71. 
Gorton, Gary, and Lixin Huang. "Banking panics and the origin of central banking." D. Altig, B. Smith (Eds.), Evolution and Procedures of Central Banking, Cambridge University Press, Cambridge (2003): 181-219

Greenlaw, David, Jan Hatzius, Anil Kashyap, and Hyun Song Shin. "Leveraged Losses: Lessons from the Mortgage Market Meltdown." In Proceedings of the US Monetary Policy Forum, vol. 2008, pp. 8-59. 2008.

Greenwood, Robin, and Samuel Hanson. "Issuer Quality and Corporate Bond Returns." Review of Financial Studies 26, no. 6 (2013): 1483-1525.

Greenwood, Robin, Samuel Hanson, and Lawrence Jin. "Reflexivity in Credit Markets." NBER Working Paper No. w25747, 2019. Available at SSRN: https://ssrn.com/abstract=3372051

Grossman, Richard. Unsettled Account: The Evolution of Banking in the Industrialized World since 1800. Princeton University Press, 2010.

He, Zhiguo, and Arvind Krishnamurthy. "Intermediary Asset Pricing." American Economic Review 103, no. 2 (2013): 732-70.

He, Zhiguo, and Wei Xiong. “Dynamic Debt Runs.” Review of Financial Studies 25, no. 6 (2012): 1799-1843.

Holmström, Bengt, and Jean Tirole. "Financial Intermediation, Loanable Funds, and the Real Sector." Quarterly Journal of Economics 112, no. 3 (1997): 663-691.

Huber, Kilian. "Disentangling the Effects of a Banking Crisis: Evidence from German Firms and Counties." American Economic Review 108, no. 3 (2018): 868-98.

Jalil, Andrew. "A New History of Banking Panics in the United States, 1825-1929: Construction and Implications." American Economic Journal: Macroeconomics 7, no. 3 (2015): 295-330.

Jordà, Òscar and Richter, Björn and Schularick, Moritz and Taylor, Alan M. "Bank Capital Redux: Solvency, Liquidity, and Crisis." NBER Working Paper No. w23287, 2017. Available at SSRN: https://ssrn.com/abstract $=2941265$

Jordà, Òscar. "Estimation and Inference of Impulse Responses by Local Projections." American Economic Review 95, no. 1 (2005): 161-182.

Kacperczyk, Marcin, and Philipp Schnabl. "When Safe Proved Risky: Commercial Paper during the Financial Crisis of 2007-2009." Journal of Economic Perspectives 24, no. 1 (2010): 29-50.

Khwaja, Asim, and Atif Mian. "Tracing the Impact of Bank Liquidity Shocks: Evidence from an Emerging Market.” American Economic Review 98, no. 4 (2008): 1413-42.

Kiefer, Nicholas, and Timothy Vogelsang. "A New Asymptotic Theory for HeteroskedasticityAutocorrelation Robust Tests." Econometric Theory 21, no. 6 (2005): 1130-1164.

Krishnamurthy, Arvind and Tyler Muir. "How Credit Cycles across a Financial Crisis." Working paper, 2018. 
Kryzanowski, Lawrence, and Gordon Roberts. "Canadian Banking Solvency, 1922-1940.” Journal of Money, Credit and Banking 25, no. 3 (1993): 361-376.

Laeven, Luc, and Fabian Valencia. "Systemic Banking Crises Database." IMF Economic Review 61, no. 2 (2013): 225-270.

López-Salido, David, Jeremy Stein, and Egon Zakrajšek. "Credit-Market Sentiment and the Business Cycle." Quarterly Journal of Economics 132, no. 3 (2017): 1373-1426.

McCabe, Patrick. "The Cross Section of Money Market Fund Risks and Financial Crises." Finance and Economics Discussion Series working paper, Federal Reserve Board, 2010.

Mian, Atif, Amir Sufi, and Emil Verner. "Household Debt and Business Cycles Worldwide." Quarterly Journal of Economics 132, no. 4 (2017): 1755-1817.

Mian, Atif, Amir Sufi, and Emil Verner. "How Does Credit Supply Expansion Affect the Real Economy? The Productive Capacity and Household Demand Channels." Journal of Finance 75, no. 2 (2019): 949-994.

Nakamura, Leonard, and Carlos Zarazaga. "Banking and finance in Argentina in the period 190035.” Working paper, (2001).

Nyberg, Peter, and Mika Vaihekoski. "A new value-weighted total return index for the Finnish stock market." In Research in international business and finance 24.3 (2010): 267-283.

Peek, Joe, and Eric Rosengren. "The Capital Crunch in New England." New England Economic Review May (1992): 21-31.

Peek, Joe, and Eric Rosengren. "Collateral Damage: Effects of the Japanese Bank Crisis on Real Activity in the United States." American Economic Review 90, no. 1 (2000): 30-45.

Puri, Manju, Jörg Rocholl, and Sascha Steffen. "Global Retail Lending in the Aftermath of the US Financial Crisis: Distinguishing Between Supply and Demand Effects." Journal of Financial Economics 100, no. 3 (2011): 556-578.

Rampini, Adriano, and S. Viswanathan. "Financial Intermediary Capital." Review of Economic Studies 86, no. 1 (2019): 413-455.

Reinhart, Carmen, and Kenneth Rogoff. This Time is Different: Eight Centuries of Financial Folly. Princeton University Press, 2009.

Romer, Christina, and David Romer. "New Evidence on the Aftermath of Financial Crises in Advanced Countries." American Economic Review 107, no. 10 (2017): 3072-3118.

Schroth, Enrique, Gustavo Suarez, and Lucian Taylor. "Dynamic Debt Runs and Financial Fragility: Evidence from the 2007 ABCP Crisis.” Journal of Financial Economics 112, no. 2 (2014): 164-189. 
Schularick, Moritz, and Alan Taylor. "Credit Booms Gone Bust: Monetary Policy, Leverage Cycles, and Financial Crises, 1870-2008." American Economic Review 102, no. 2 (2012): 1029-61.

Schwartz, Anna. "Real and Pseudo-Financial Crises." In Money in Historical Perspective, pp. 271288. University of Chicago Press, 1987.

Shizume, Masato. "The Japanese Economy during the Interwar Period: Instability in the Financial System and the Impact of the World Depression." In The Gold Standard Peripheries, pp. 211228. Palgrave Macmillan, London, 2012.

Stock, James, and Mark Watson. "Forecasting Output and Inflation: The Role of Asset Prices." Journal of Economic Literature 41, no. 3 (2003): 788-829.

Syron, Richard. “Are We Experiencing a Credit Crunch?” New England Economic Review, July (1991): 3-10.

Waldenström, Daniel. “Swedish stock and bond returns, 1856-2012.” Working paper, 2014. 
Figure 1: Dynamics of output and credit around bank equity crashes

This figure presents the average dynamics of real GDP and credit-to-GDP around 30\% bank equity crashes. Bank equity crashes are defined to occur in year $t=0$. Each panel plots cumulative growth in a given variable from five years before a bank equity crash $(t=-5)$ to five years after the crash $(t=5)$. For comparison, average dynamics around years with no crash are presented in red.

\section{(A) Real GDP}

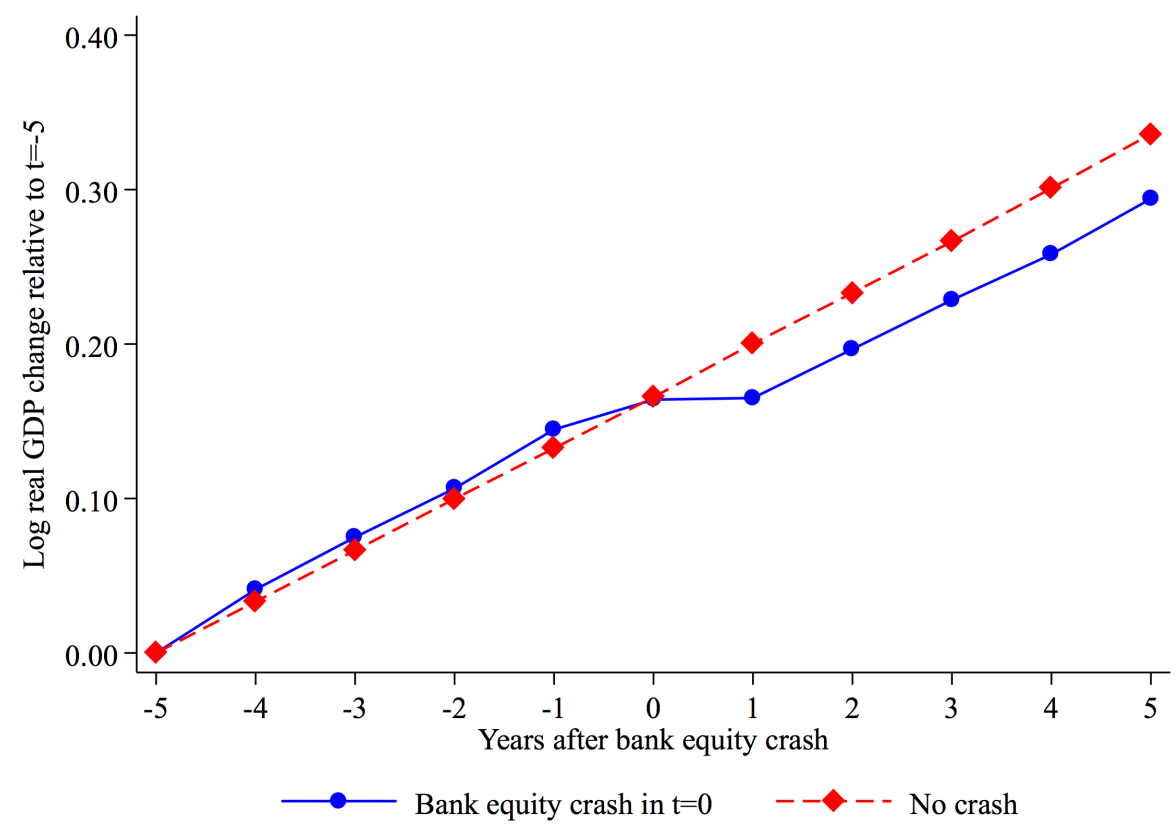

(B) Credit-to-GDP

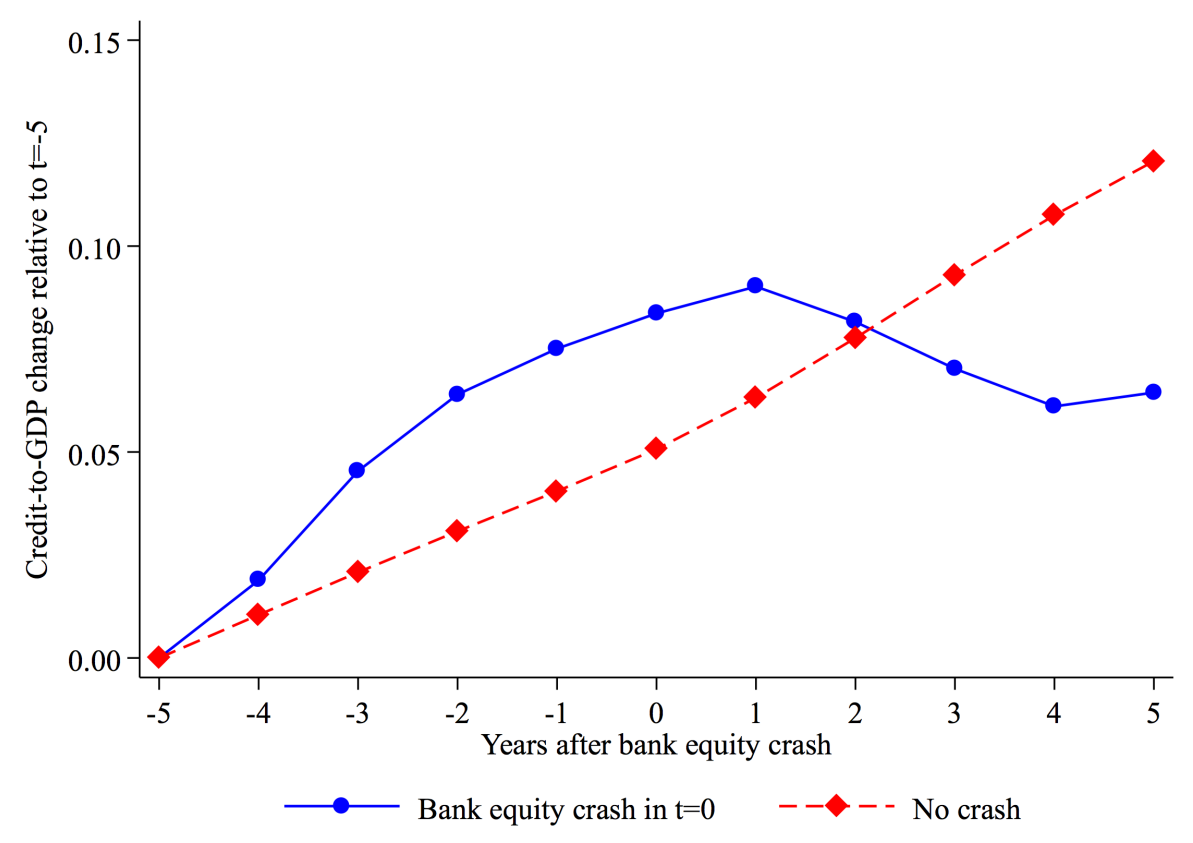


Figure 2: Bank equity crashes predict output gaps and credit contraction

This figure plots the impact of bank equity and nonfinancial equity returns on real GDP (Panel A) and bank credit-to-GDP (Panel B). The responses are estimated jointly using Equation 1, which includes eight bins of bank and nonfinancial equity returns to capture the predictive content across the return distribution. The specification controls for country fixed effects, contemporaneous real GDP growth and change in credit-to-GDP, and three lags of real GDP growth, change in credit-toGDP, and bank and nonfinancial equity return bins. The responses to bank equity and nonfinancial equity returns are estimated jointly. The x-axis is time in years, and the y-axis is real GDP or bank credit-to-GDP relative to the omitted return bin (return between 0\% and 15\%).

(A) Real GDP response

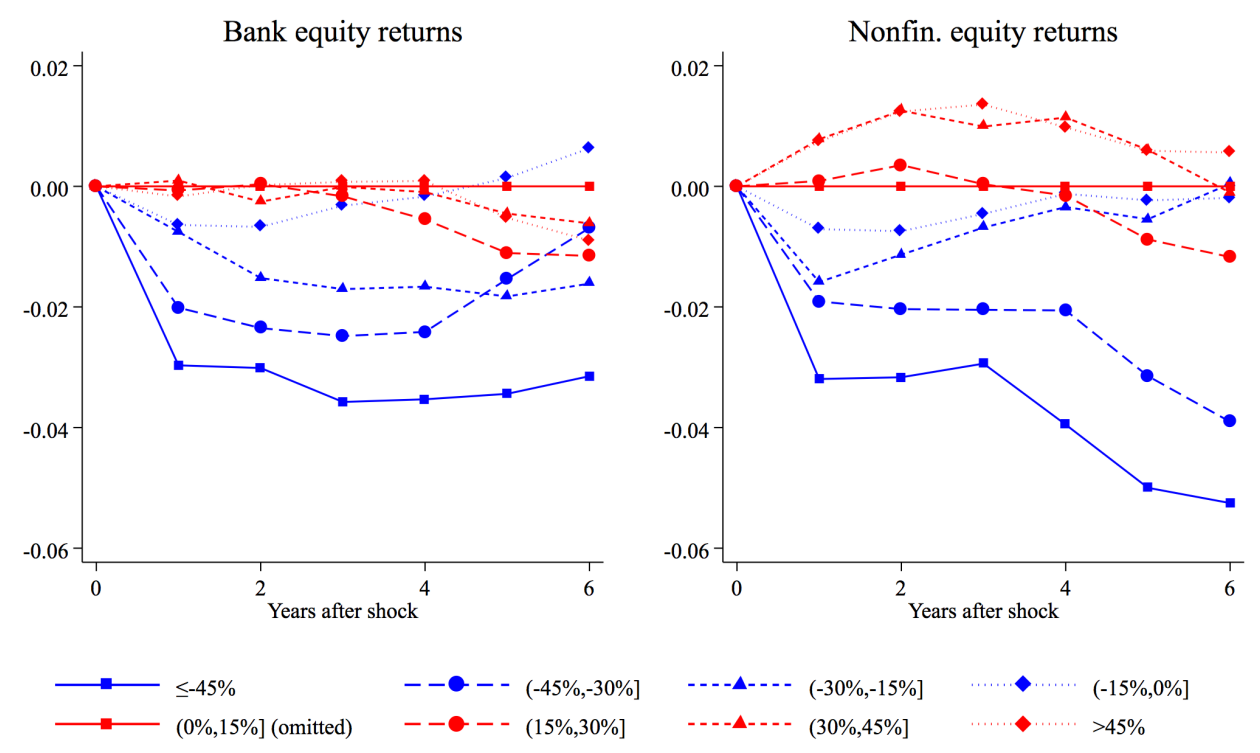

(B) Credit-to-GDP response

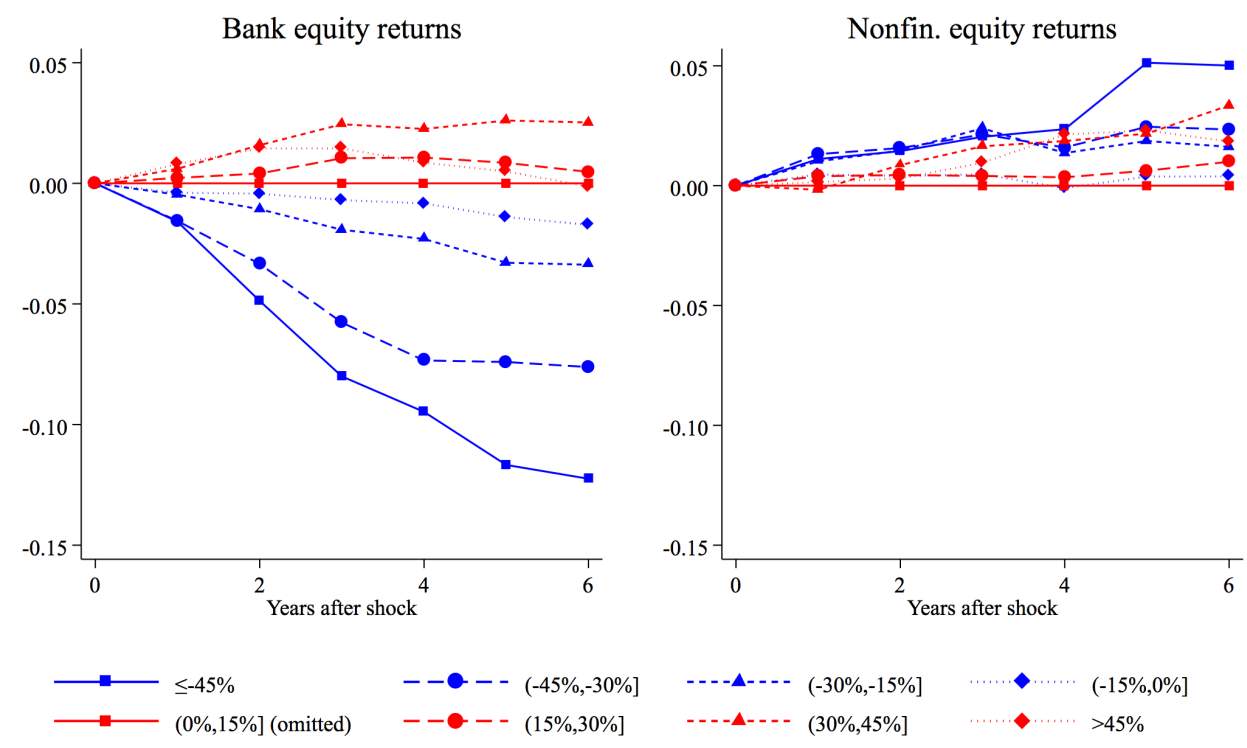


Figure 3: Banking distress with and without banking panics

This figure presents the response of real GDP and credit-to-GDP to $30 \%$ bank equity crashes, distinguishing between $30 \%$ bank equity crashes that coincide with a banking panic and crashes that are not associated with a panic. The impulse responses are estimated from Equation 3. Panel A presents the results from the baseline specification. Panel B analyzes episodes with a $30 \%$ bank equity crash and narrative evidence of widespread bank failures. The specification controls for country fixed effects, contemporaneous real GDP growth and change in credit-to-GDP, and three lags of real GDP growth, change in credit-to-GDP, and bank and nonfinancial equity return bins. The dashed lines represent $95 \%$ confidence intervals based on Driscoll-Kraay standard errors with a lag length of six.

(A) Baseline
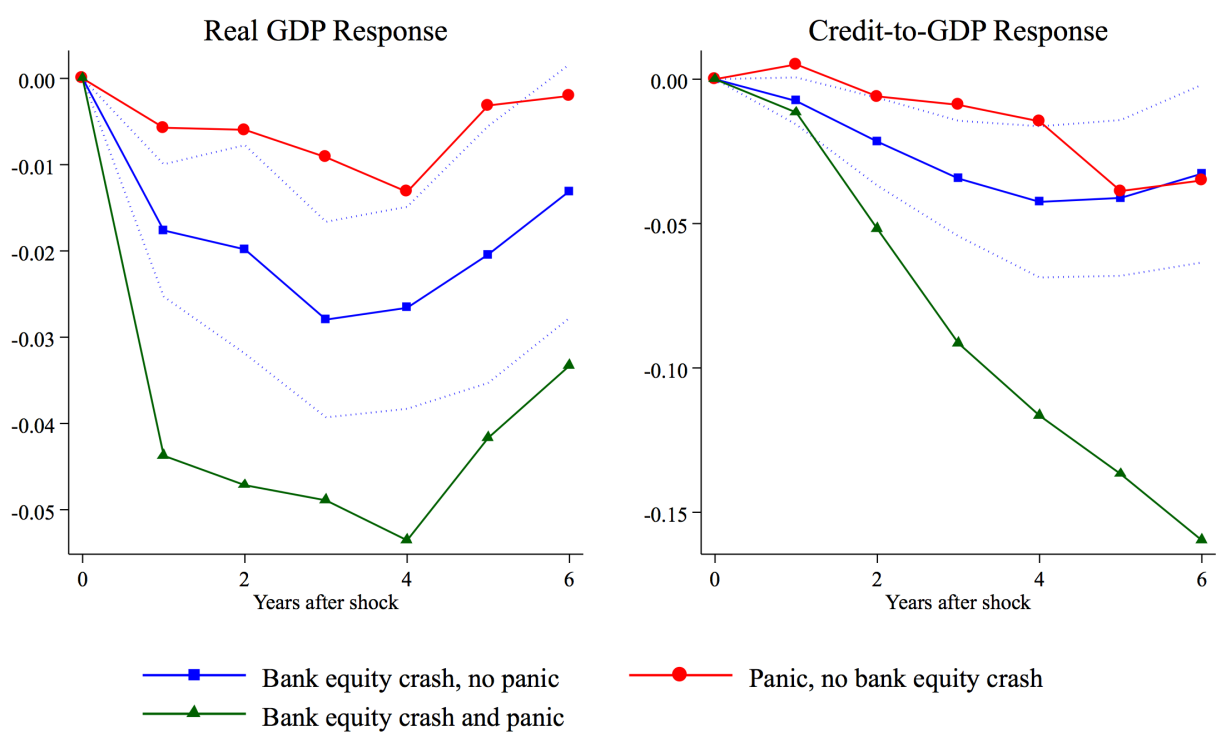

(B) Conditioning on bank failures
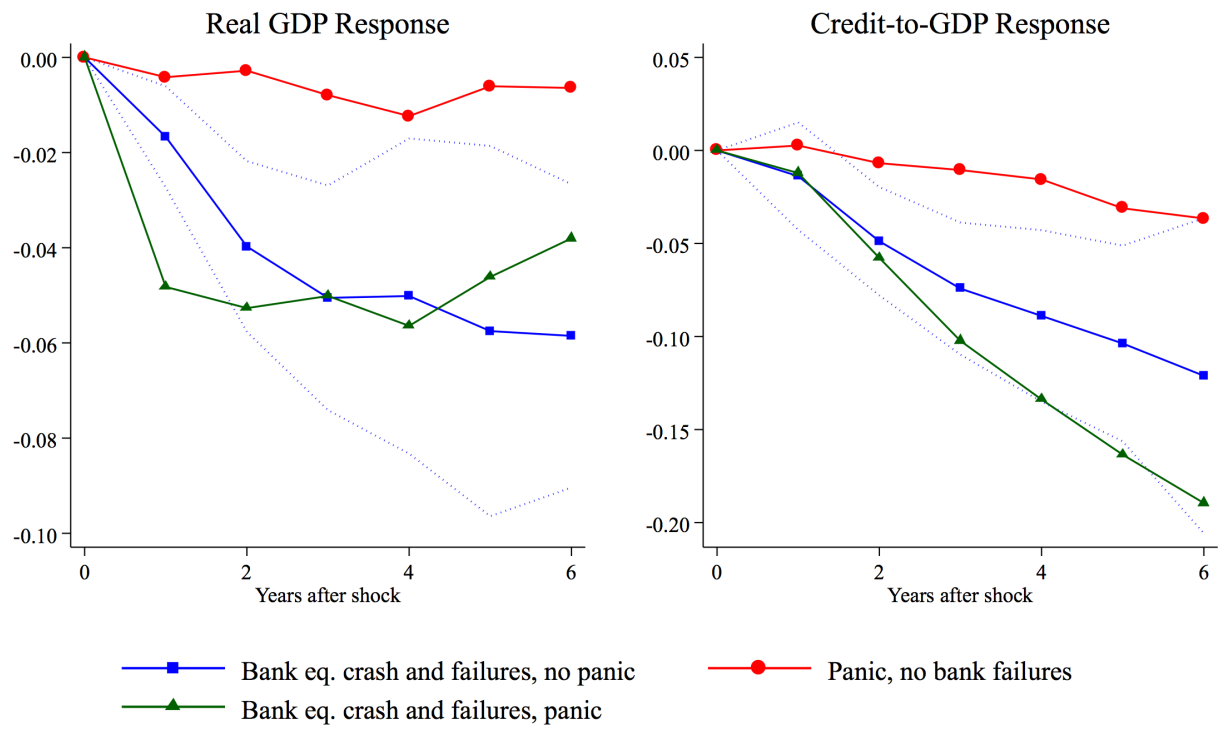
Figure 4: Impact of bank equity crashes outside of narrative banking crisis episodes This figure shows that bank equity crashes predict output gaps and credit contraction even excluding episodes with narrative evidence of panics or widespread bank failures. Local projection impulse responses are estimated as in Figure 2 but exclude observations within a \pm 3 -year window around a panic or an episode of widespread bank failures.

(A) Real GDP response

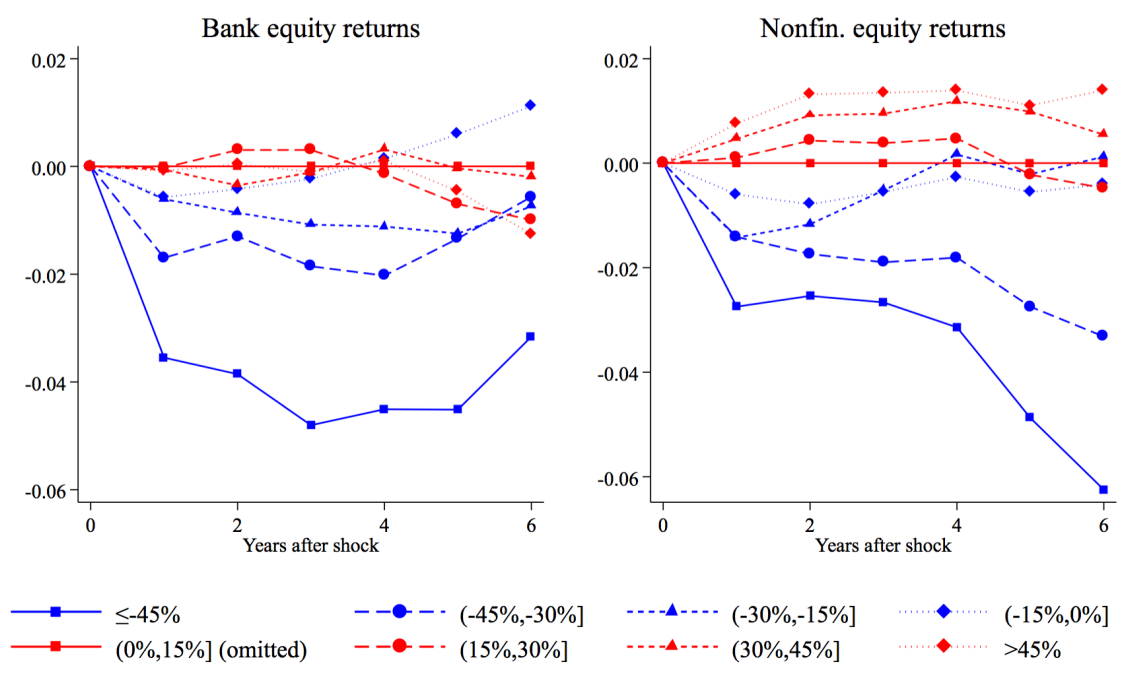

(B) Credit-to-GDP response

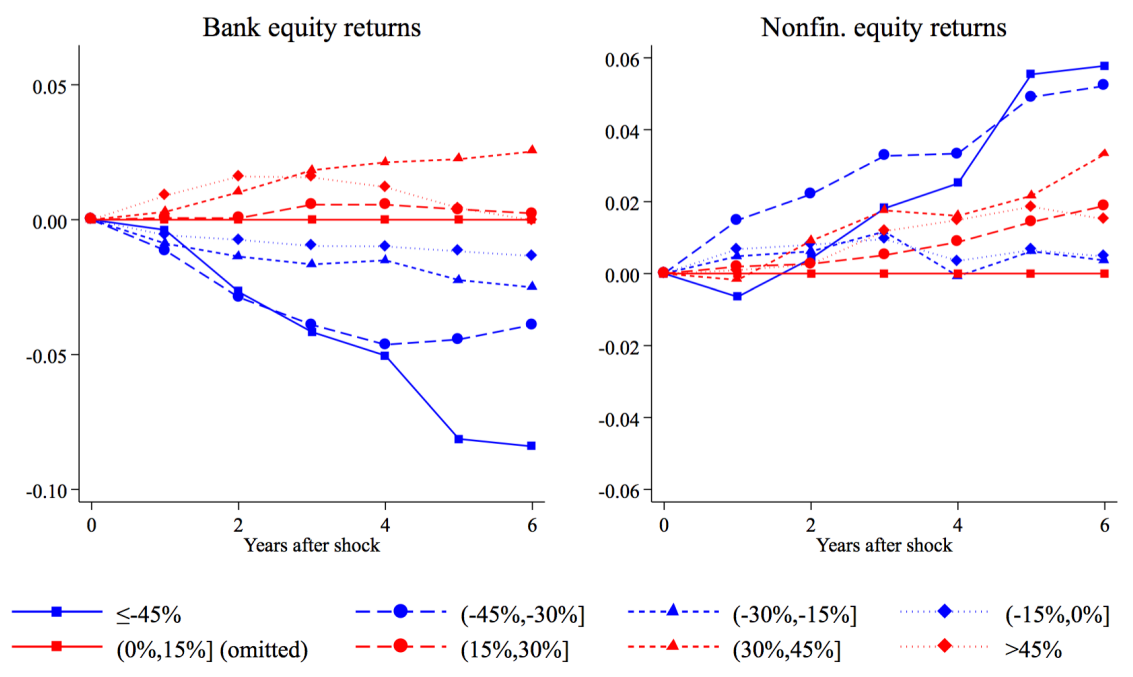


Figure 5: Equity returns and credit spreads around the U.S. 2007-8 banking crisis

This figure plots bank and nonfinancial equity total return indexes and credit spreads around the U.S. 2007-8 banking crisis. The bank equity index is in blue, the nonfinancial equity index is in red, corporate credit spreads are in black (dashed is the AAA 10-year Corporate minus 10-year Treasury spread, solid is the BAA minus AAA 10-year Corporate spread), and the 3-month LIBOR minus OIS spread is in green. The scale on the left corresponds to equity returns, and the scale on the right corresponds to bond yield spreads.

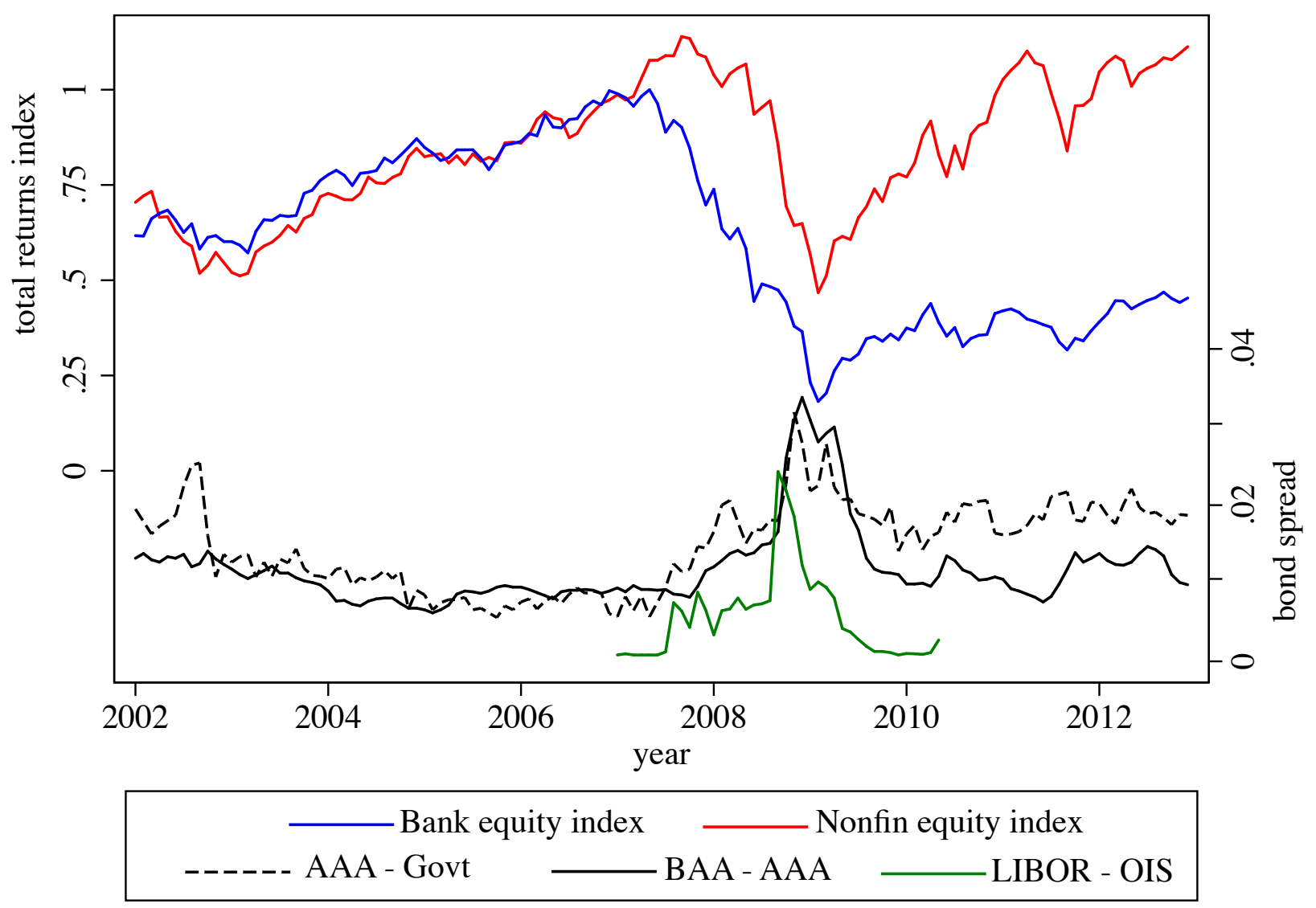


Figure 6: Timing of bank equity declines relative to panics and other financial market indicators

This figure compares the average evolution, around BVX Crises, of monthly bank equity returns relative to a series of other financial market indicators. The other financial market indicators are nonfinancial equity returns, bank credit spreads, corporate credit spreads, and the first month of a banking panic based on narrative accounts. Equity returns correspond to the left axis, and credit spreads correspond to the right axis. Equity indexes and credit spreads are normalized to 0 in event month 0, defined as January of the BVX crisis year. The curve representing the Start of Panic is a frequency plot of the first month of the banking panic based on narrative accounts. The Start of Panic curve corresponds to a third axis that we omit to minimize clutter, but the area under this curve is one. Panel A presents results for the full sample, Panel B uses a sample where bank equity, nonfinancial equity, and bank credit spreads are all non-missing, and Panels $\mathrm{C}$ to E present results across subsamples.

(A) Full sample

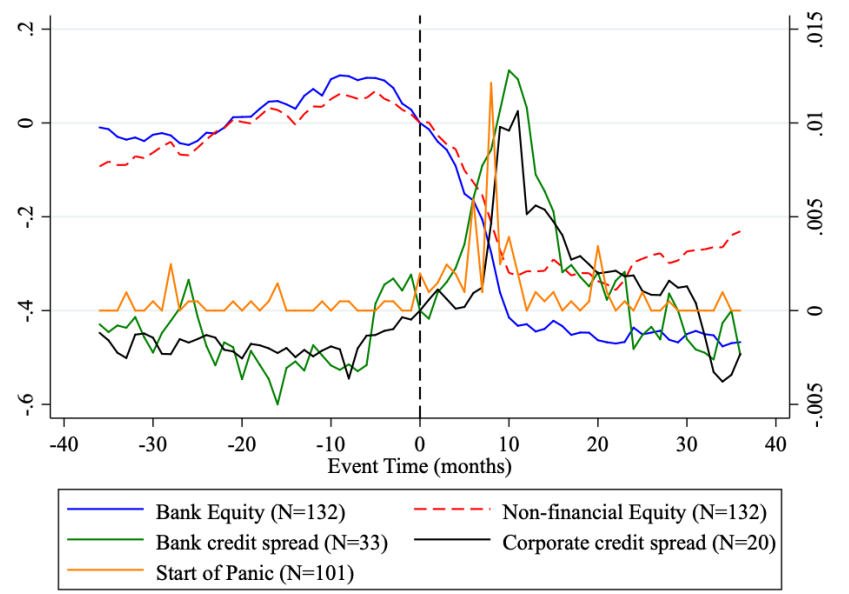

(B) Consistent sample

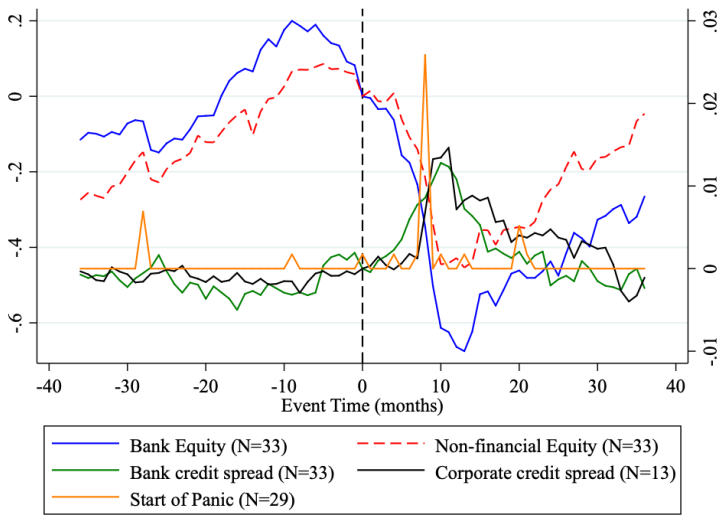

(D) $1940-2016$

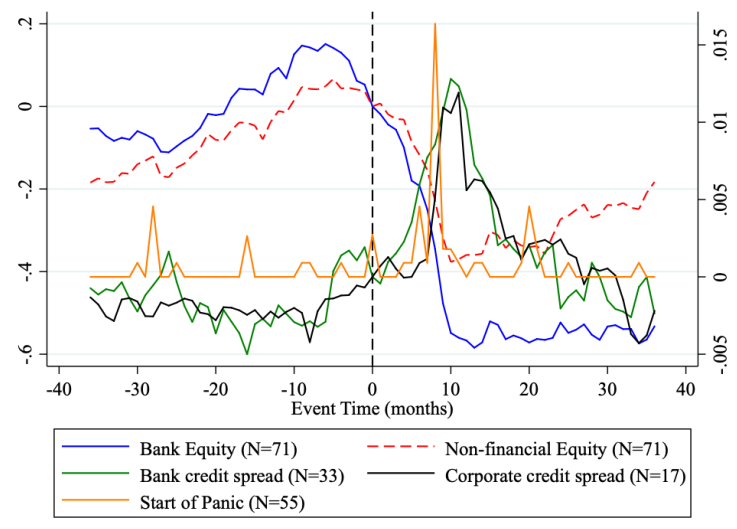

(C) 1870-1939

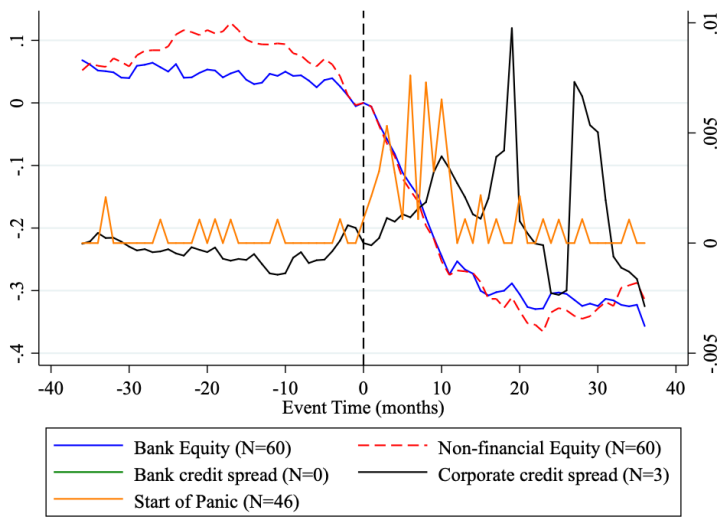

(E) 1940-2006

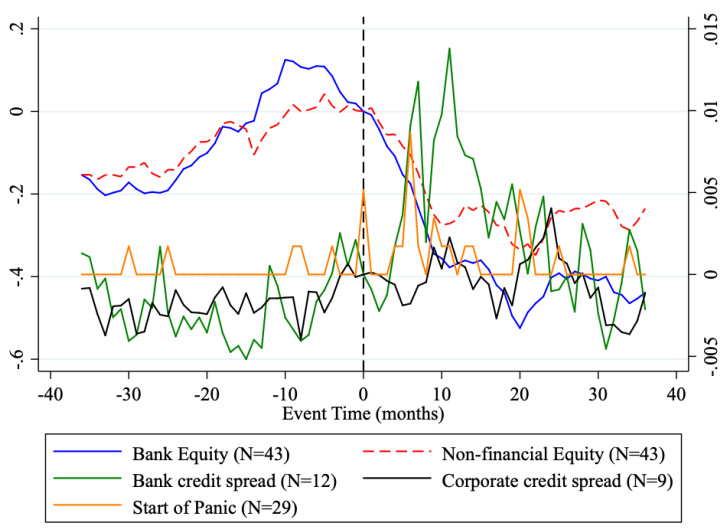


Figure 7: Bank equity falls substantially before the start of banking panics

This figure illustrates that bank equity falls substantially (on average by 36\%) before a banking panic. Panel A shows the distribution of bank equity returns from its previous peak to the month before a panic. The unit of observation is an episode in which a panic occurred and the month of the panic is known. Panel B is the bank equity decline from Panel A normalized by the eventual total peak-to-trough decline.

(A) Bank equity decline up to month before panic

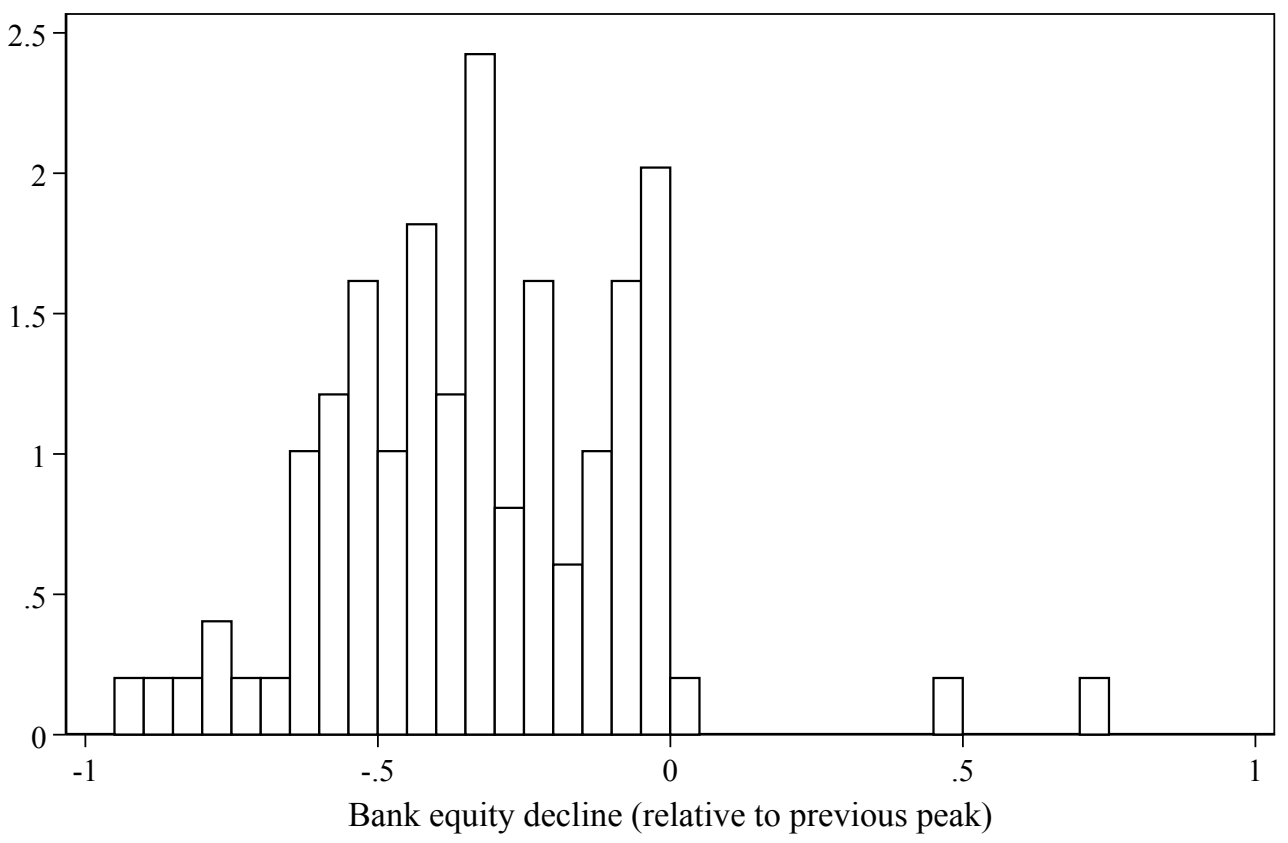

(B) As a percentage of total eventual peak-to-trough decline

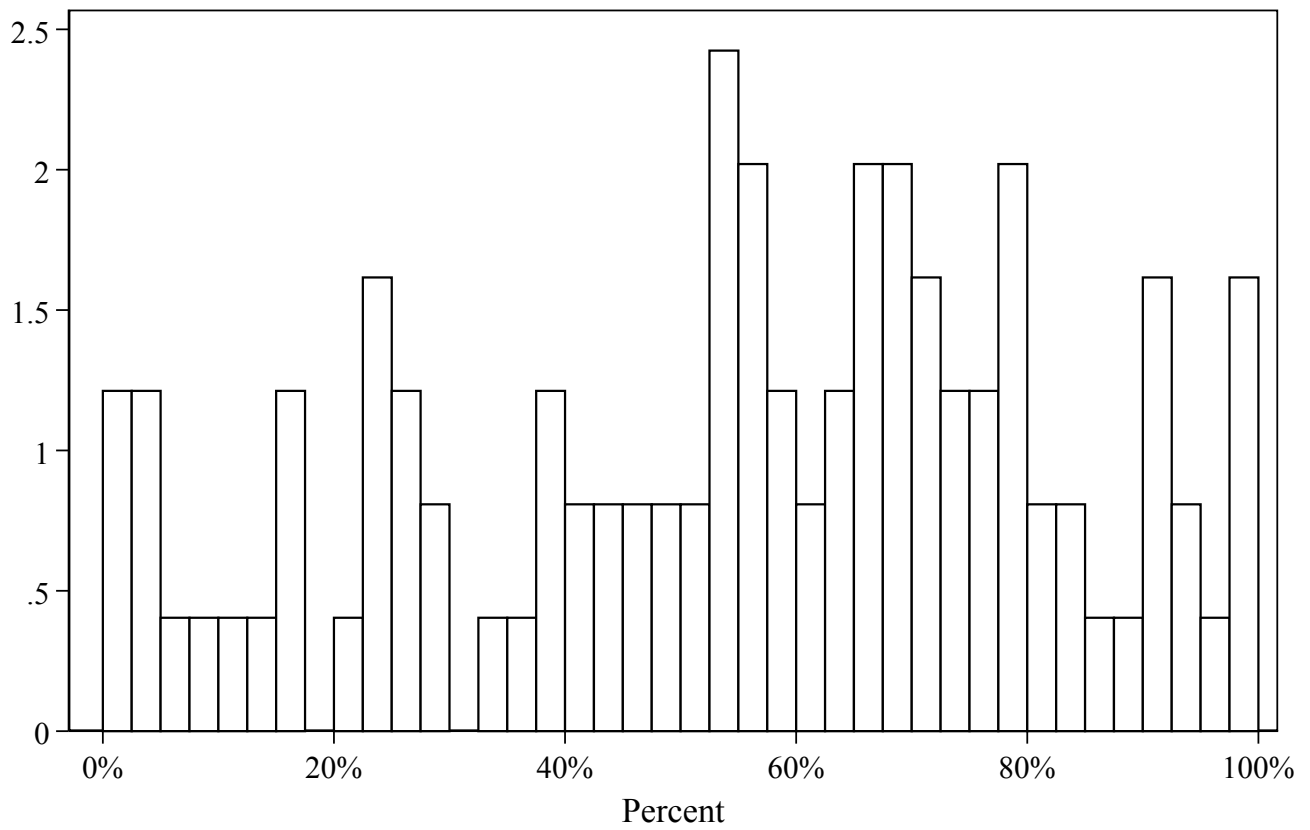


Table 1: Narrative-based banking crises in Germany

This table illustrates disagreement among narrative-based chronologies regarding the occurrence of historical banking crises, focusing on the case of Germany (similar results hold for other countries, see Appendix Table A1). It lists the occurrence of banking crises according to six prominent papers. Years listed correspond to the starting year of the banking crisis, according to each paper. A "0" means that the source reports no banking crisis in a given year, while a blank cell means that the crisis is not covered in the sample period. Note that Demirguc-Kunt and Detragiache (2005) focus on the period 1980-2002 and do not report any crises for Germany during this period.

\begin{tabular}{cccccc}
\hline $\begin{array}{c}\text { Reinhart } \\
\text { Rogoff }\end{array}$ & $\begin{array}{c}\text { Schularick } \\
\text { Taylor }\end{array}$ & $\begin{array}{c}\text { Laeven } \\
\text { Valencia }\end{array}$ & Bordo & $\begin{array}{c}\text { Caprio } \\
\text { Klingebiel }\end{array}$ & $\begin{array}{c}\text { Demirguc-Kunt } \\
\text { \& Detragiache }\end{array}$ \\
\hline 0 & 1873 & & & & \\
1880 & 0 & & 0 & & \\
1891 & 1891 & & 1901 & & \\
1901 & 1901 & & 0 & \\
0 & 1907 & & 0 & \\
1925 & 0 & & 1931 & \\
1929 & 1931 & 0 & 0 & late 1970s \\
1977 & 0 & 0 & & 0 \\
2008 & 2008 & 2008 & & & \\
\hline
\end{tabular}


Table 2: Bank equity crashes predict output gaps and credit contraction

This table shows that bank equity crashes predict lower subsequent real GDP and credit-to-GDP. The results are estimated using Equation 2. A bank (nonfinancial) equity crash is defined as $30 \%$ decline in the bank (nonfinancial) equity real total return index from year $t-1$ to year $t$. Controls are contemporaneous real GDP growth and credit-to-GDP change, as well as three lags in the bank equity crash indicator, nonfinancial equity crash indicator, credit-to-GDP change, and real GDP growth. $t$-statistics in brackets are computed from Driscoll-Kraay standard errors with a lag length of six. $*, * *, * * *$ indicate significance at the $0.1,0.05$, and 0.01 levels, respectively, computed from fixed-b p-values based on Kiefer and Vogelsang (2005).

Panel A: Real GDP growth

\begin{tabular}{|c|c|c|c|c|c|c|}
\hline & \multicolumn{3}{|c|}{ Real GDP growth $_{t, t+1}$} & \multicolumn{3}{|c|}{ Real GDP growth $_{t, t+3}$} \\
\hline & (1) & $(2)$ & $(3)$ & $(4)$ & $(5)$ & $(6)$ \\
\hline Bank equity crash & $\begin{array}{c}-0.033^{* * *} \\
{[-9.90]}\end{array}$ & $\begin{array}{c}-0.026^{* * *} \\
{[-8.12]}\end{array}$ & $\begin{array}{c}-0.019^{* * *} \\
{[-8.45]}\end{array}$ & $\begin{array}{c}-0.045^{* * *} \\
{[-6.20]}\end{array}$ & $\begin{array}{c}-0.034^{* * *} \\
{[-5.92]}\end{array}$ & $\begin{array}{c}-0.029^{* * *} \\
{[-8.05]}\end{array}$ \\
\hline Nonfinancial equity crash & $\begin{array}{c}-0.023^{* * *} \\
{[-3.87]}\end{array}$ & $\begin{array}{c}-0.022^{* * *} \\
{[-5.12]}\end{array}$ & $\begin{array}{c}-0.010^{* *} \\
{[-2.36]}\end{array}$ & $\begin{array}{c}-0.031^{* *} \\
{[-2.61]}\end{array}$ & $\begin{array}{c}-0.029^{* *} \\
{[-2.83]}\end{array}$ & $\begin{array}{c}-0.023^{* *} \\
{[-2.77]}\end{array}$ \\
\hline $\begin{array}{l}\text { Country fixed effects } \\
\text { Controls } \\
\text { Year fixed effects } \\
\text { Adj. } R^{2} \text { (within) } \\
\text { N }\end{array}$ & $\begin{array}{c}0.11 \\
2548\end{array}$ & $\begin{array}{l}0.19 \\
2548\end{array}$ & $\begin{array}{c}\checkmark \\
\checkmark \\
\checkmark \\
0.09 \\
2548\end{array}$ & $\begin{array}{l}0.05 \\
2548\end{array}$ & $\begin{array}{c}0.11 \\
2548\end{array}$ & $\begin{array}{c}\checkmark \\
\checkmark \\
\checkmark \\
0.07 \\
2548\end{array}$ \\
\hline \multicolumn{7}{|c|}{ Panel B: Credit-to-GDP change } \\
\hline & \multicolumn{3}{|c|}{ Credit-to-GDP change $_{t, t+1}$} & \multicolumn{3}{|c|}{ Credit-to-GDP change ${ }_{t, t+3}$} \\
\hline & $(1)$ & $(2)$ & $(3)$ & $(4)$ & $(5)$ & $(6)$ \\
\hline Bank equity crash & $\begin{array}{c}-0.020^{* *} \\
{[-2.81]}\end{array}$ & $\begin{array}{l}-0.010 \\
{[-1.72]}\end{array}$ & $\begin{array}{c}-0.011^{*} \\
{[-2.07]}\end{array}$ & $\begin{array}{c}-0.077^{* * *} \\
{[-6.10]}\end{array}$ & $\begin{array}{c}-0.057^{* * *} \\
{[-5.08]}\end{array}$ & $\begin{array}{c}-0.051^{* * *} \\
{[-4.70]}\end{array}$ \\
\hline Nonfinancial equity crash & $\begin{array}{c}0.010^{* *} \\
{[2.72]} \\
\end{array}$ & $\begin{array}{c}0.0071^{* *} \\
{[2.36]} \\
\end{array}$ & $\begin{array}{c}0.0031 \\
{[0.82]} \\
\end{array}$ & $\begin{array}{c}0.0077 \\
{[0.71]} \\
\end{array}$ & $\begin{array}{c}0.0035 \\
{[0.37]} \\
\end{array}$ & $\begin{array}{c}-0.0038 \\
{[-0.32]} \\
\end{array}$ \\
\hline Country fixed effects & $\checkmark$ & $\checkmark$ & $\checkmark$ & $\checkmark$ & $\checkmark$ & $\checkmark$ \\
\hline Controls & & $\checkmark$ & $\checkmark$ & & $\checkmark$ & $\checkmark$ \\
\hline Year fixed effects & & & $\checkmark$ & & & $\checkmark$ \\
\hline Adj. $R^{2}$ (within) & 0.01 & 0.22 & 0.21 & 0.03 & 0.14 & 0.13 \\
\hline $\mathrm{N}$ & 2535 & 2535 & 2535 & 2535 & 2535 & 2535 \\
\hline
\end{tabular}


Table 3: Impact of banking distress with and without panics

This table presents the response of real GDP and credit-to-GDP to $30 \%$ bank equity crashes, distinguishing between $30 \%$ bank equity crashes that coincide with a banking panic and crashes that are not associated with a panic. The coefficients are estimated from Equation 3. Panel A presents the results from the baseline specification. Panel B defines episodes of banking sector distress as years with a $30 \%$ bank equity crash and narrative evidence of widespread bank failures ("Bank eq. crash and failures"). The specification controls for country fixed effects, contemporaneous real GDP growth and change in credit-to-GDP, and three lags of real GDP growth, change in creditto-GDP, and all right-hand-side variables in the table. $t$-statistics in brackets are computed from Driscoll-Kraay standard errors with a lag length of six. ${ }^{*}, * *, * * *$ indicate significance at the 0.1 , 0.05, and 0.01 levels, respectively, computed from fixed-b $p$-values of Kiefer and Vogelsang (2005).

Panel A: Baseline

\begin{tabular}{|c|c|c|c|c|c|c|}
\hline & \multicolumn{3}{|c|}{ Real GDP growth $_{t, t+3}$} & \multicolumn{3}{|c|}{ 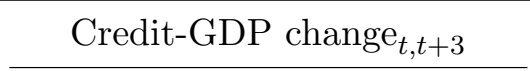 } \\
\hline & (1) & $(2)$ & $(3)$ & $(4)$ & (5) & (6) \\
\hline Bank equity crash & $\begin{array}{c}-0.030^{* * *} \\
{[-3.95]}\end{array}$ & $\begin{array}{c}-0.028^{* * *} \\
{[-4.88]}\end{array}$ & $\begin{array}{c}-0.023^{* * *} \\
{[-5.60]}\end{array}$ & $\begin{array}{c}-0.050^{* * *} \\
{[-3.95]}\end{array}$ & $\begin{array}{c}-0.034^{* * *} \\
{[-3.40]}\end{array}$ & $\begin{array}{c}-0.032^{* * *} \\
{[-2.80]}\end{array}$ \\
\hline Panic & $\begin{array}{c}-0.022^{* *} \\
{[-2.27]}\end{array}$ & $\begin{array}{c}-0.0091 \\
{[-0.93]}\end{array}$ & $\begin{array}{c}0.0034 \\
{[0.37]}\end{array}$ & $\begin{array}{c}0.0046 \\
{[0.32]}\end{array}$ & $\begin{array}{c}-0.0089 \\
{[-0.65]}\end{array}$ & $\begin{array}{c}-0.0084 \\
{[-0.56]}\end{array}$ \\
\hline Bank equity crash $\times$ Panic & $\begin{array}{c}-0.026^{* *} \\
{[-2.61]}\end{array}$ & $\begin{array}{l}-0.012 \\
{[-1.37]}\end{array}$ & $\begin{array}{c}-0.021^{* *} \\
{[-2.71]}\end{array}$ & $\begin{array}{c}-0.075^{* * *} \\
{[-3.26]}\end{array}$ & $\begin{array}{c}-0.048^{*} \\
{[-1.99]}\end{array}$ & $\begin{array}{c}-0.044^{*} \\
{[-1.77]}\end{array}$ \\
\hline Nonfinancial equity crash & $\begin{array}{c}-0.029^{* *} \\
{[-2.39]}\end{array}$ & $\begin{array}{c}-0.028^{* *} \\
{[-2.72]}\end{array}$ & $\begin{array}{c}-0.024^{* *} \\
{[-2.77]}\end{array}$ & $\begin{array}{c}0.0092 \\
{[0.77]}\end{array}$ & $\begin{array}{c}0.0038 \\
{[0.38]}\end{array}$ & $\begin{array}{c}-0.0044 \\
{[-0.36]}\end{array}$ \\
\hline Country fixed effects & $\checkmark$ & $\checkmark$ & $\checkmark$ & $\checkmark$ & $\checkmark$ & $\checkmark$ \\
\hline Controls & & $\checkmark$ & $\checkmark$ & & $\checkmark$ & $\checkmark$ \\
\hline Year fixed effects & & & $\checkmark$ & & & $\checkmark$ \\
\hline Adj. $R^{2}$ (within) & 0.06 & 0.11 & 0.07 & 0.03 & 0.15 & 0.13 \\
\hline $\mathrm{N}$ & 2548 & 2548 & 2548 & 2536 & 2536 & 2536 \\
\hline
\end{tabular}

Panel B: Conditioning on bank failures

\begin{tabular}{|c|c|c|c|c|c|c|}
\hline & \multicolumn{3}{|c|}{ Real GDP growth $_{t, t+3}$} & \multicolumn{3}{|c|}{ 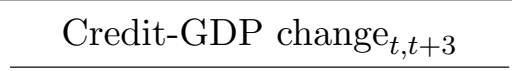 } \\
\hline & (1) & $(2)$ & (3) & $(4)$ & $(5)$ & (6) \\
\hline Bank eq. crash and failures & $\begin{array}{c}-0.062^{* * *} \\
{[-4.04]}\end{array}$ & $\begin{array}{c}-0.051^{* * *} \\
{[-4.23]}\end{array}$ & $\begin{array}{c}-0.039^{* * *} \\
{[-4.50]}\end{array}$ & $\begin{array}{c}-0.11^{* * *} \\
{[-3.99]}\end{array}$ & $\begin{array}{c}-0.074^{* * *} \\
{[-4.14]}\end{array}$ & $\begin{array}{c}-0.074^{* * *} \\
{[-4.50]}\end{array}$ \\
\hline Panic & $\begin{array}{c}-0.024^{* *} \\
{[-2.58]}\end{array}$ & $\begin{array}{c}-0.0079 \\
{[-0.74]}\end{array}$ & $\begin{array}{c}0.00022 \\
{[0.018]}\end{array}$ & $\begin{array}{c}0.0021 \\
{[0.17]}\end{array}$ & $\begin{array}{l}-0.011 \\
{[-0.87]}\end{array}$ & $\begin{array}{c}-0.0081 \\
{[-0.59]}\end{array}$ \\
\hline Bank eq. crash and failures $\times$ Panic & $\begin{array}{c}0.0062 \\
{[0.38]}\end{array}$ & $\begin{array}{c}0.0083 \\
{[0.51]}\end{array}$ & $\begin{array}{c}0.0036 \\
{[0.23]}\end{array}$ & $\begin{array}{l}-0.028 \\
{[-0.84]}\end{array}$ & $\begin{array}{l}-0.018 \\
{[-0.64]}\end{array}$ & $\begin{array}{l}-0.014 \\
{[-0.51]}\end{array}$ \\
\hline Nonfinancial equity crash & $\begin{array}{c}-0.037^{* * *} \\
{[-4.07]}\end{array}$ & $\begin{array}{c}-0.036^{* * *} \\
{[-4.55]}\end{array}$ & $\begin{array}{c}-0.029^{* * *} \\
{[-3.32]}\end{array}$ & $\begin{array}{c}-0.0044 \\
{[-0.54]}\end{array}$ & $\begin{array}{c}-0.0046 \\
{[-0.59]}\end{array}$ & $\begin{array}{c}-0.0078 \\
{[-0.70]}\end{array}$ \\
\hline Country fixed effects & $\checkmark$ & $\checkmark$ & $\checkmark$ & $\checkmark$ & $\checkmark$ & $\checkmark$ \\
\hline Controls & & $\checkmark$ & $\checkmark$ & & $\checkmark$ & $\checkmark$ \\
\hline Year fixed effects & & & $\checkmark$ & & & $\checkmark$ \\
\hline Adj. $R^{2}$ (within) & 0.06 & 0.11 & 0.07 & 0.03 & 0.16 & 0.15 \\
\hline $\mathrm{N}$ & 2548 & 2548 & 2548 & 2536 & 2536 & 2536 \\
\hline
\end{tabular}


Table 4: Timing of bank equity crashes relative to panics, nonfinancial equity crashes, and credit spread spikes

This table analyzes monthly data around BVX Crisis List episodes to compare the relative timing of various other financial market indicators. Panel A compares the timing of $30 \%$ bank equity crashes with the panic start date, credit spread spikes, and narrative crisis start dates. The time difference is positive if the bank equity crash is recorded before the other event and negative if after the event. Panel B column 1 records the average time difference in months between detecting a $30 \%$ bank equity crash relative to a $30 \%$ nonfinancial equity crash. Column 2 records the average time difference in months between a bank equity peak and a nonfinancial equity peak. Column 3 records the average duration of a bank equity crash from peak to trough. For each column in all panels, a $t$-statistic is calculated under the null hypothesis that the average time difference is zero. As an alternative non-parametric test, we also count the number of episodes the bank equity decline is recorded first ("pos"), the other event is recorded first ("neg"), or both events are recorded in the same month ("zero"). We then calculate the fraction of times that the bank equity decline happens first ("pos / (pos + neg)") and calculate a $p$-value under the null hypothesis that the bank equity decline happening first is Bernoulli-distributed with parameter 0.50. ******* indicate significance at the $0.1,0.05$, and 0.01 levels, respectively.

Panel A: Bank equity crashes detect the crisis before panics, credit spread spikes, and narrative

\begin{tabular}{|c|c|c|c|c|c|c|c|}
\hline & Before panic & $\begin{array}{c}\text { Before } \\
\text { Reinhart- } \\
\text { Rogoff start } \\
\text { dates }\end{array}$ & $\begin{array}{c}\text { Before earliest } \\
\text { narrative start } \\
\text { dates }\end{array}$ & $\begin{array}{c}\text { Before } 2 \% \\
\text { spike in bank } \\
\text { credit spread }\end{array}$ & $\begin{array}{c}\text { Before } 1 \% \\
\text { spike in bank } \\
\text { credit spread }\end{array}$ & $\begin{array}{c}\text { Before } 2 \% \\
\text { spike in corp } \\
\text { credit spread }\end{array}$ & $\begin{array}{c}\text { Before } 1 \% \\
\text { spike in corp } \\
\text { credit spread }\end{array}$ \\
\hline $\begin{array}{l}\text { Average } \\
\text { (in months, signed) }\end{array}$ & $7.46^{* * *}$ & $3.22^{* *}$ & $2.94^{* *}$ & $6.10^{* * *}$ & $3.37^{* *}$ & $9.11^{* * *}$ & $4.11^{*}$ \\
\hline t-stat & 4.92 & 2.52 & 2.43 & 5.87 & 1.97 & 6.65 & 1.75 \\
\hline $\mathrm{N}$ & 93 & 94 & 102 & 40 & 41 & 19 & 19 \\
\hline Pos & 69 & 39 & 33 & 32 & 23 & 16 & 12 \\
\hline Zero & 5 & 33 & 53 & 4 & 2 & 1 & 0 \\
\hline Neg & 19 & 22 & 16 & 4 & 16 & 2 & 7 \\
\hline Pos / (Pos + Neg $)$ & $78.4 \% * * *$ & $63.9 \% * *$ & $67.3 \% * *$ & $88.89 \% * * *$ & $59.0 \%$ & $88.9 \% * * *$ & $63.2 \%$ \\
\hline p-value & 0.000 & 0.020 & 0.011 & 0.000 & 0.168 & 0.001 & 0.180 \\
\hline
\end{tabular}

Panel B: Bank equity crashes pick up the crisis first before nonfinancial equity crashes

\begin{tabular}{|c|c|c|c|}
\hline & $\begin{array}{l}\text { Before nonfin. } \\
\text { eq. crash }\end{array}$ & $\begin{array}{c}\text { Bank equity peaks before } \\
\text { nonfin. eq. peak }\end{array}$ & Duration of bank equity decline \\
\hline Average (in months, signed) & $1.94^{* *}$ & $1.37^{* *}$ & $27.17^{* * *}$ \\
\hline t-stat & 2.44 & 2.11 & 24.32 \\
\hline $\mathrm{N}$ & 127 & 138 & 140 \\
\hline Pos & 65 & 56 & Duration $\geq 24$ mo. $=85$ episodes \\
\hline Zero & 16 & 40 & \\
\hline Neg & 46 & 42 & Duration $<24$ mo. $=55$ episodes \\
\hline Pos / (Pos + Neg $)$ & $58.56 \% * *$ & $57.1 \% *$ & $\%$ Duration $\geq 24$ mo. $=61 \% * * *$ \\
\hline p-value & 0.044 & 0.094 & 0.007 \\
\hline
\end{tabular}


Table 5: Distribution of credit spread increases just after bank equity crashes

This table presents the distribution of credit spread increases just after bank equity crashes around BVX Crisis List episodes. Each row presents the distribution of credit spread increases in the month following a given decrease in bank stocks (relative to the previous bank stock peak). For example, the third row of Panel A reports the distribution of credit spread increases when the bank equity index first falls by more than 30\%. Panel A presents the analysis for bank credit spreads, and Panel B presents the analysis for corporate credit spreads.

Panel A: The distribution of bank credit spread increases subsequent to bank equity crashes

\begin{tabular}{|c|c|c|c|c|c|c|c|c|c|}
\hline & $\begin{array}{l}\ldots \text { bank } c \\
10^{\text {th }} \text { pctile }\end{array}$ & $\begin{array}{l}\text { edit spreads } \\
20^{\text {th }} \text { pctile }\end{array}$ & $\begin{array}{l}\text { increase by } \\
30^{\text {th }} \text { pctile }\end{array}$ & $\begin{array}{l}\text { n percentag } \\
40^{\text {th }} \text { pctile }\end{array}$ & $\begin{array}{l}\text { points): } \\
50^{\text {th }} \text { pctile }\end{array}$ & $60^{\text {th }}$ pctile & $70^{\text {th }}$ pctile & $80^{\text {th }}$ pctile & $90^{\text {th }}$ pctile \\
\hline \multicolumn{10}{|l|}{$\begin{array}{l}\text { When banks stocks } \\
\text { fall more than... }\end{array}$} \\
\hline$-20 \%$ & 0.00 & 0.00 & 0.00 & 0.00 & 0.00 & 0.00 & 0.10 & 0.29 & 0.40 \\
\hline$-25 \%$ & 0.00 & 0.00 & 0.00 & 0.01 & 0.29 & 0.36 & 0.49 & 0.59 & 0.63 \\
\hline$-30 \%$ & 0.00 & 0.00 & 0.29 & 0.36 & 0.52 & 0.55 & 0.62 & 0.85 & 1.09 \\
\hline$-35 \%$ & 0.29 & 0.36 & 0.44 & 0.52 & 0.63 & 0.68 & 0.85 & 1.10 & 1.30 \\
\hline$-40 \%$ & 0.52 & 0.52 & 0.54 & 0.68 & 0.85 & 0.86 & 1.23 & 1.35 & 2.02 \\
\hline$-45 \%$ & 0.69 & 0.69 & 0.78 & 0.99 & 1.29 & 1.33 & 2.02 & 2.50 & 2.50 \\
\hline$-50 \%$ & 0.98 & 0.98 & 0.99 & 1.33 & 2.27 & 2.40 & 2.81 & 3.26 & 5.19 \\
\hline$-55 \%$ & 1.14 & 1.14 & 2.27 & 2.88 & 3.26 & 3.26 & 6.71 & 6.49 & 7.11 \\
\hline
\end{tabular}

Panel B: The distribution of corporate credit spread increases subsequent to bank equity crashes

\begin{tabular}{|c|c|c|c|c|c|c|c|c|c|}
\hline & $\begin{array}{l}\ldots \text { corpora } \\
10^{\text {th }} \text { pctile }\end{array}$ & $\begin{array}{l}20^{\text {th }} \text { pctile }\end{array}$ & $\begin{array}{l}\text { ads increase } \\
30^{\text {th }} \text { pctile }\end{array}$ & $\begin{array}{l}\text { by (in perce } \\
40^{\text {th }} \text { pctile }\end{array}$ & $\begin{array}{l}\text { tage points): } \\
50^{\text {th }} \text { pctile }\end{array}$ & $60^{\text {th }}$ pctile & $70^{\text {th }}$ pctile & $80^{\text {th }}$ pctile & $90^{\text {th }}$ pctile \\
\hline \multicolumn{10}{|l|}{$\begin{array}{l}\text { When banks stocks } \\
\text { fall more than... }\end{array}$} \\
\hline$-20 \%$ & 0.00 & 0.00 & 0.00 & 0.00 & 0.00 & 0.00 & 0.00 & 0.00 & 0.09 \\
\hline$-25 \%$ & 0.00 & 0.00 & 0.00 & 0.00 & 0.00 & 0.00 & 0.00 & 0.00 & 0.39 \\
\hline$-30 \%$ & 0.00 & 0.00 & 0.00 & 0.00 & 0.02 & 0.23 & 0.23 & 0.15 & 1.00 \\
\hline$-35 \%$ & 0.00 & 0.00 & 0.11 & 0.19 & 0.27 & 0.34 & 0.34 & 0.32 & 1.14 \\
\hline$-40 \%$ & 0.00 & 0.12 & 0.27 & 0.29 & 0.41 & 0.45 & 0.45 & 0.41 & 1.30 \\
\hline$-45 \%$ & 0.36 & 0.36 & 0.59 & 0.73 & 0.86 & 0.96 & 0.96 & 1.06 & 1.49 \\
\hline$-50 \%$ & 0.86 & 0.86 & 1.16 & 1.25 & 1.35 & 1.41 & 1.41 & 1.45 & 1.88 \\
\hline$-55 \%$ & 1.13 & 1.13 & 1.54 & 1.57 & 1.59 & 1.61 & 1.61 & 2.67 & 3.31 \\
\hline
\end{tabular}


Table 6: The BVX Crisis List

This table lists a chronology of banking crisis episodes, covering 46 countries over the period 1870-2016, which we refer to as the BVX Crisis List. The BVX Crisis List is then divided into two (non-mutually exclusive) types of banking crisis episodes: those featuring a panic ("Panic banking crisis") and those featuring both a $30 \%$ bank equity crash and evidence of widespread bank failures ("Bank equity crisis"). Newly-identified banking crises (i.e., those that did not previously appear on the Narrative Crises list) are marked with a "*". The column labeled "Bank equity return" reports the peak-to-trough real total return for each episode, which is computed as the maximum cumulative decline (based on annual data) in the bank equity real total return index relative to its previous peak. "0" indicates no decline in bank equity. A blank entry indicates a lack of bank equity return data for that episode.

\begin{tabular}{|c|c|c|c|c|c|c|c|c|c|c|c|c|c|c|}
\hline Country & $\begin{array}{c}\text { BVX } \\
\text { starting } \\
\text { year }\end{array}$ & $\begin{array}{l}\text { Bank } \\
\text { equity } \\
\text { return }\end{array}$ & $\begin{array}{c}\text { Panic } \\
\text { banking } \\
\text { crisis }\end{array}$ & $\begin{array}{c}\text { Bank } \\
\text { equity } \\
\text { crisis }\end{array}$ & Country & $\begin{array}{c}\text { BVX } \\
\text { starting } \\
\text { year }\end{array}$ & $\begin{array}{l}\text { Bank } \\
\text { equity } \\
\text { return }\end{array}$ & $\begin{array}{c}\text { Panic } \\
\text { banking } \\
\text { crisis }\end{array}$ & $\begin{array}{c}\text { Bank } \\
\text { equity } \\
\text { crisis }\end{array}$ & Country & $\begin{array}{c}\text { BVX } \\
\text { starting } \\
\text { year }\end{array}$ & $\begin{array}{l}\text { Bank } \\
\text { equity } \\
\text { return }\end{array}$ & $\begin{array}{c}\text { Panic } \\
\text { banking } \\
\text { crisis }\end{array}$ & $\begin{array}{r}\text { Bank } \\
\text { equity } \\
\text { crisis }\end{array}$ \\
\hline \multirow[t]{9}{*}{ Argentina } & 1891 & -0.307 & 1 & 1 & Chile (cont.) & 1914 & & 1 & 0 & Greece & 1929 & -0.727 & 1 & 1 \\
\hline & 1914 & -0.473 & 1 & 0 & & 1925 & & 1 & 1 & & 2008 & -0.671 & 1 & 0 \\
\hline & 1930 & -0.819 & 1 & 0 & & $1931^{*}$ & -0.356 & 1 & 1 & & $2010^{*}$ & -0.961 & 1 & 1 \\
\hline & 1934 & -0.563 & 1 & 1 & & 1976 & 0 & 1 & 0 & Hong Kong & $1892^{*}$ & -0.565 & 1 & 1 \\
\hline & 1980 & & 1 & 1 & & 1982 & -0.837 & 1 & 1 & & 1965 & -0.196 & 1 & 0 \\
\hline & 1985 & & 1 & 1 & Colombia & $1931^{*}$ & -0.675 & 1 & 0 & & 1982 & -0.445 & 1 & 1 \\
\hline & 1989 & & 1 & 1 & & 1982 & -0.831 & 0 & 1 & & 1991 & -0.096 & 1 & 0 \\
\hline & 1995 & -0.305 & 1 & 1 & & 1998 & -0.813 & 1 & 1 & & 1998 & -0.464 & 1 & 1 \\
\hline & 2000 & -0.656 & 1 & 1 & Czech & 1923 & & 1 & 1 & Hungary & $1873^{*}$ & -0.518 & 1 & 1 \\
\hline \multirow[t]{3}{*}{ Australia } & 1893 & -0.469 & 1 & 1 & & 1991 & & 1 & 1 & & 1931 & & 1 & 1 \\
\hline & 1931 & -0.230 & 1 & 0 & & 1995 & -0.904 & 1 & 1 & & 1991 & & 0 & 1 \\
\hline & 1989 & -0.281 & 1 & 0 & Denmark & 1877 & -0.207 & 1 & 0 & & $1995^{*}$ & -0.398 & 1 & 1 \\
\hline \multirow[t]{5}{*}{ Austria } & 1873 & -0.715 & 1 & 1 & & 1885 & -0.043 & 1 & 0 & & 2008 & -0.671 & 1 & 0 \\
\hline & 1924 & -0.344 & 0 & 1 & & 1907 & -0.269 & 1 & 0 & Iceland & $1920^{*}$ & -0.535 & 1 & 1 \\
\hline & 1931 & -0.566 & 1 & 1 & & 1919 & -0.347 & 1 & 1 & & $1930^{*}$ & -0.359 & 1 & 1 \\
\hline & 2008 & -0.673 & 1 & 1 & & 1992 & -0.425 & 0 & 1 & & 1985 & & 0 & 1 \\
\hline & $2011^{*}$ & -0.509 & 0 & 1 & & 2008 & -0.739 & 1 & 1 & & 1993 & & 0 & 1 \\
\hline \multirow[t]{8}{*}{ Belgium } & 1870 & -0.018 & 1 & 0 & & $2011^{*}$ & -0.444 & 0 & 1 & & 2008 & -0.963 & 1 & 1 \\
\hline & $1876^{*}$ & -0.374 & 1 & 1 & Egypt & 1907 & -0.132 & 1 & 0 & India & 1913 & -0.249 & 1 & 0 \\
\hline & 1883 & -0.139 & 1 & 0 & & 1914 & -0.407 & 1 & 0 & & 1920 & -0.495 & 0 & 1 \\
\hline & 1914 & & 1 & 1 & & 1931 & -0.608 & 1 & 1 & & 1993 & -0.561 & 0 & 1 \\
\hline & 1929 & -0.831 & 1 & 1 & Finland & 1900 & & 1 & 1 & Indonesia & 1990 & -0.659 & 1 & 1 \\
\hline & 1939 & -0.511 & 1 & 1 & & 1921 & -0.569 & 0 & 1 & & 1998 & -0.88 & 1 & 1 \\
\hline & 2008 & -0.842 & 1 & 1 & & 1931 & -0.252 & 1 & 0 & Ireland & 2007 & -0.918 & 1 & 1 \\
\hline & 2011* & -0.755 & 0 & 1 & & 1990 & -0.814 & 1 & 1 & & $2010^{*}$ & -0.908 & 1 & 1 \\
\hline \multirow[t]{7}{*}{ Brazil } & 1890 & -0.275 & 1 & 0 & France & 1871 & & 1 & 0 & Israel & 1983 & -0.499 & 0 & 1 \\
\hline & 1900 & 0 & 1 & 0 & & 1882 & -0.456 & 1 & 1 & Italy & 1873 & -0.237 & 1 & 0 \\
\hline & 1914 & -0.374 & 1 & 0 & & 1889 & -0.106 & 1 & 0 & & 1889 & -0.348 & 1 & 1 \\
\hline & 1929 & -0.182 & 1 & 0 & & 1914 & -0.475 & 1 & 0 & & 1891 & -0.453 & 1 & 1 \\
\hline & 1985 & & 1 & 1 & & 1930 & -0.571 & 1 & 1 & & 1907 & -0.24 & 1 & 1 \\
\hline & 1990 & & 1 & 0 & & $1937^{*}$ & -0.435 & 1 & 0 & & 1914 & -0.333 & 1 & 1 \\
\hline & 1994 & & 1 & 1 & & 2008 & -0.64 & 1 & 0 & & 1921 & -0.55 & 1 & 1 \\
\hline \multirow[t]{3}{*}{ Canada } & 1873 & 0 & 1 & 0 & Germany & 1874 & -0.371 & 1 & 1 & & 1930 & -0.073 & 1 & 0 \\
\hline & 1920 & -0.426 & 1 & 1 & & 1891 & -0.23 & 1 & 0 & & 1992 & -0.397 & 0 & 1 \\
\hline & 1982 & -0.164 & 1 & 0 & & 1901 & -0.05 & 1 & 0 & & 2008 & -0.575 & 1 & 0 \\
\hline \multirow[t]{3}{*}{ Chile } & 1878 & & 1 & 1 & & 1914 & & 1 & 0 & & $2011^{*}$ & -0.601 & 0 & 1 \\
\hline & 1898 & -0.003 & 1 & 0 & & 1930 & -0.489 & 1 & 1 & & $2016^{*}$ & -0.304 & 0 & 1 \\
\hline & 1907 & & 1 & 1 & & 2008 & -0.728 & 1 & 1 & & & & & \\
\hline
\end{tabular}


Table 6: The BVX Crisis List (cont.)

\begin{tabular}{|c|c|c|c|c|c|c|c|c|c|c|c|c|c|c|}
\hline Country & $\begin{array}{c}\text { BVX } \\
\text { starting } \\
\text { year }\end{array}$ & $\begin{array}{l}\text { Bank } \\
\text { equity } \\
\text { return }\end{array}$ & $\begin{array}{c}\text { Panic } \\
\text { banking } \\
\text { crisis }\end{array}$ & $\begin{array}{c}\text { Bank } \\
\text { equity } \\
\text { crisis }\end{array}$ & Country & $\begin{array}{c}\text { BVX } \\
\text { starting } \\
\text { year }\end{array}$ & $\begin{array}{l}\text { Bank } \\
\text { equity } \\
\text { return }\end{array}$ & $\begin{array}{c}\text { Panic } \\
\text { banking } \\
\text { crisis }\end{array}$ & $\begin{array}{l}\text { Bank } \\
\text { equity } \\
\text { crisis }\end{array}$ & Country & $\begin{array}{c}\text { BVX } \\
\text { starting } \\
\text { year }\end{array}$ & $\begin{array}{l}\text { Bank } \\
\text { equity } \\
\text { return }\end{array}$ & $\begin{array}{c}\text { Panic } \\
\text { banking } \\
\text { crisis }\end{array}$ & $\begin{array}{c}\text { Bank } \\
\text { equity } \\
\text { crisis }\end{array}$ \\
\hline \multirow[t]{12}{*}{ Japan } & 1871 & & 1 & 1 & Peru & 1876 & & 1 & 1 & Switzerland & 1870 & -0.418 & 1 & 0 \\
\hline & 1882 & & 1 & 1 & & $1914^{*}$ & -0.612 & 1 & 0 & & 1914 & & 1 & 0 \\
\hline & 1890 & & 1 & 1 & & $1931^{*}$ & -0.373 & 1 & 1 & & 1919 & -0.432 & 0 & 1 \\
\hline & 1901 & -0.221 & 1 & 0 & & 1981 & -0.980 & 0 & 1 & & 1931 & -0.559 & 1 & 1 \\
\hline & 1907 & -0.377 & 1 & 1 & & 1998 & -0.396 & 0 & 1 & & 1990 & -0.326 & 1 & 1 \\
\hline & 1920 & -0.405 & 1 & 1 & Philippines & $1971^{*}$ & -0.781 & 1 & 0 & & 2008 & -0.676 & 1 & 0 \\
\hline & $1922 *$ & -0.405 & 1 & 1 & & 1981 & -0.719 & 1 & 1 & Taiwan & 1923 & & 1 & 0 \\
\hline & 1923 & -0.157 & 1 & 1 & & 1997 & -0.687 & 0 & 1 & & 1927 & & 1 & 1 \\
\hline & 1927 & -0.168 & 1 & 0 & Portugal & 1876 & & 1 & 1 & & 1983 & & 1 & 1 \\
\hline & 1990 & -0.546 & 0 & 1 & & 1890 & & 1 & 1 & & 1995 & -0.307 & 1 & 1 \\
\hline & 1997 & -0.605 & 1 & 1 & & 1921 & -0.643 & 1 & 1 & & 1998 & -0.557 & 0 & 1 \\
\hline & $2001^{*}$ & -0.808 & 0 & 1 & & 1923 & -0.684 & 1 & 1 & Thailand & 1979 & -0.461 & 0 & 1 \\
\hline Korea & 1997 & -0.726 & 1 & 1 & & 1931 & -0.597 & 1 & 1 & & 1983 & 0 & 1 & 0 \\
\hline Luxembourg & 2008 & -0.474 & 1 & 1 & & 2008 & -0.613 & 1 & 1 & & 1997 & -0.734 & 1 & 1 \\
\hline \multirow[t]{2}{*}{ Malaysia } & 1985 & -0.368 & 1 & 1 & & $2011^{*}$ & -0.725 & 0 & 1 & Turkey & $1914^{*}$ & -0.654 & 1 & 1 \\
\hline & 1997 & -0.686 & 1 & 1 & & $2014^{*}$ & -0.800 & 0 & 1 & & 1930 & -0.719 & 1 & 1 \\
\hline \multirow[t]{7}{*}{ Mexico } & 1883 & & 1 & 1 & Russia & 1875 & -0.188 & 1 & 0 & & 1980 & -0.409 & 1 & 1 \\
\hline & 1893 & -0.325 & 1 & 0 & & 1900 & -0.401 & 1 & 1 & & 1991 & -0.758 & 1 & 0 \\
\hline & 1913 & -0.596 & 1 & 1 & & 1995 & & 1 & 1 & & 1994 & -0.203 & 1 & 0 \\
\hline & 1921 & & 1 & 1 & & 1998 & -0.751 & 1 & 1 & & 2001 & -0.622 & 1 & 1 \\
\hline & 1928 & -0.839 & 1 & 1 & & 2008 & -0.723 & 1 & 1 & U.K. & 1878 & -0.132 & 1 & 0 \\
\hline & 1981 & & 1 & 1 & Singapore & (no crises) & & & & & 1890 & -0.128 & 1 & 0 \\
\hline & 1994 & -0.602 & 1 & 1 & South Africa & 1881 & -0.27 & 1 & 0 & & 1914 & & 1 & 0 \\
\hline \multirow[t]{5}{*}{ Netherlands } & 1907 & -0.083 & 1 & 0 & & 1890 & -0.062 & 1 & 0 & & 1973 & -0.737 & 1 & 1 \\
\hline & 1914 & -0.093 & 1 & 0 & Spain & 1882 & -0.349 & 1 & 1 & & 1991 & -0.147 & 1 & 0 \\
\hline & 1921 & -0.334 & 0 & 1 & & 1890 & -0.124 & 1 & 0 & & 2008 & -0.707 & 1 & 1 \\
\hline & $1931^{*}$ & -0.418 & 0 & 1 & & 1913 & -0.038 & 1 & 0 & U.S. & 1873 & -0.172 & 1 & 0 \\
\hline & 2008 & -0.562 & 1 & 1 & & 1920 & -0.14 & 1 & 0 & & 1884 & 0 & 1 & 0 \\
\hline \multirow[t]{2}{*}{ New Zealand } & 1888 & -0.549 & 1 & 1 & & 1924 & -0.222 & 1 & 0 & & 1890 & 0 & 1 & 0 \\
\hline & 1987 & -0.892 & 1 & 1 & & 1931 & -0.336 & 1 & 1 & & 1893 & -0.29 & 1 & 0 \\
\hline \multirow[t]{8}{*}{ Norway } & 1898 & & 1 & 1 & & 1975 & -0.814 & 0 & 1 & & 1907 & -0.334 & 1 & 1 \\
\hline & 1914 & & 1 & 0 & & 2008 & -0.466 & 1 & 1 & & 1930 & -0.654 & 1 & 1 \\
\hline & 1919 & -0.71 & 1 & 1 & & $2010^{*}$ & -0.411 & 0 & 1 & & 1984 & -0.263 & 1 & 0 \\
\hline & 1931 & 0 & 1 & 0 & Sweden & 1878 & & 1 & 1 & & 1990 & -0.332 & 0 & 1 \\
\hline & 1987 & -0.464 & 1 & 1 & & 1907 & -0.135 & 1 & 0 & & 2007 & -0.676 & 1 & 1 \\
\hline & $2008^{*}$ & -0.670 & 1 & 0 & & 1919 & -0.395 & 0 & 1 & Venezuela & 1981 & -0.34 & 1 & 1 \\
\hline & & & & & & 1991 & -0.787 & 1 & 1 & & 1992 & -0.839 & 1 & 1 \\
\hline & & & & & & 2008 & -0.519 & 1 & 1 & & 2008 & -0.614 & 1 & 1 \\
\hline
\end{tabular}


Table 7: BVX Crisis List summary statistics

This table reports average outcomes for episodes on the BVX Crisis List, BVX Crisis List episodes having a bank equity decline of more than $-30 \%$, newly-uncovered banking crises on the BVX Crisis List, and episodes that are recorded as crises on the list of Narrative Crises but that do not appear on the BVX Crisis List ("Removed crises").

\begin{tabular}{|c|c|c|c|c|c|c|c|c|}
\hline \multirow[b]{2}{*}{ Bank equity decline } & \multicolumn{2}{|c|}{ BVX Crisis List } & \multicolumn{2}{|c|}{$\begin{array}{c}\text { BVX Crisis List } \\
\text { (Bank equity } \\
\text { decline }>-30 \% \text { ) }\end{array}$} & \multicolumn{2}{|c|}{$\begin{array}{c}\text { Newly-uncovered } \\
\text { crises }\end{array}$} & \multicolumn{2}{|c|}{ Removed crises } \\
\hline & -0.462 & $(\mathrm{~N}=183)$ & -0.603 & $(\mathrm{~N}=113)$ & -0.550 & $(\mathrm{~N}=27)$ & -0.116 & $(\mathrm{~N}=47)$ \\
\hline Abnormal bank equity decline & -0.344 & $(\mathrm{~N}=170)$ & -0.420 & $(\mathrm{~N}=99)$ & -0.329 & $(\mathrm{~N}=22)$ & -0.180 & $(\mathrm{~N}=45)$ \\
\hline Bank market cap decline & -0.416 & $(\mathrm{~N}=79)$ & -0.523 & $(\mathrm{~N}=53)$ & -0.536 & $(\mathrm{~N}=13)$ & -0.116 & $(\mathrm{~N}=23)$ \\
\hline Real GDP decline (pk to tr) & -0.055 & $(\mathrm{~N}=210)$ & -0.063 & $(\mathrm{~N}=109)$ & -0.082 & $(\mathrm{~N}=30)$ & -0.021 & $(\mathrm{~N}=54)$ \\
\hline Real GDP growth decline (pk to tr) & -0.085 & $(\mathrm{~N}=209)$ & -0.091 & $(\mathrm{~N}=108)$ & -0.085 & $(\mathrm{~N}=29)$ & -0.057 & $(\mathrm{~N}=54)$ \\
\hline Real GDP growth (max dev from trend) & -0.060 & $(\mathrm{~N}=210)$ & -0.066 & $(\mathrm{~N}=111)$ & -0.072 & $(\mathrm{~N}=30)$ & -0.036 & $(\mathrm{~N}=54)$ \\
\hline Failed banks ( $\%$ of total bank assets) & 0.296 & $(\mathrm{~N}=66)$ & 0.317 & $(\mathrm{~N}=47)$ & 0.322 & $(\mathrm{~N}=1)$ & 0.060 & $(\mathrm{~N}=11)$ \\
\hline NPL at peak & 0.171 & $(\mathrm{~N}=79)$ & 0.170 & $(\mathrm{~N}=61)$ & 0.188 & $(\mathrm{~N}=9)$ & 0.054 & $(\mathrm{~N}=8)$ \\
\hline Decline in deposits (pre-war only) & -0.196 & $(\mathrm{~N}=49)$ & -0.209 & $(\mathrm{~N}=24)$ & -0.143 & $(\mathrm{~N}=3)$ & -0.051 & $(\mathrm{~N}=18)$ \\
\hline Significant liability guarantees & 0.561 & $(\mathrm{~N}=148)$ & 0.638 & $(\mathrm{~N}=94)$ & 0.545 & $(\mathrm{~N}=22)$ & 0.357 & $(\mathrm{~N}=28)$ \\
\hline Significant liquidity support & 0.761 & $(\mathrm{~N}=159)$ & 0.827 & $(\mathrm{~N}=98)$ & 0.783 & $(\mathrm{~N}=23)$ & 0.407 & $(\mathrm{~N}=27)$ \\
\hline
\end{tabular}

